\title{
Yoksulluk Sorunu İçin \\ Hegel'in Sistemine İçkin Bir Çözümün İmkânı
}

\author{
SEDA AKAY ATASOY ${ }^{1}$
}

${ }^{1}$ PhD Candidate, Hacettepe University, Department of Philosophy (Orcid ID: 0000-0001-8736-

7777)

\begin{abstract}
Özet
Hegel, yoksulluk sorununu devlet aşamasına geçişte sivil topluma özgü bir sorun olarak ele almakta ve bu sorunun radikal bir soruna kendi emeği ile yaşamak onurunu, hukuka olan saygısını ve kendine olan güvenini kaybetmiş bir yığın olan ayaktakımı ile dönüştüğünü öne sürmektedir. Yoksulluk sorununa Hegel tarafından çeşitli çözüm önerileri getirilse de literatürdeki pek çok çalışmada bu öneriler yetersiz bulunmakta ya da Hegel'in sorunu çözümsüz bıraktığı ifade edilmektedir. Bu çalışmada yoksulluk sorununa Hegel'in düşünce sistemi dışına çıkılmaksızın korporasyon temelli bir çözüm önerisi getirilmektedir. Bu kapsamda yoksulluk için doğrudan devlet müdahalesi veya tam refah devleti oluşumu içermeyen aşamalı bir çözüm öngörülmekte, çözümün sivil toplum aşamasında gerçekleşmesi ve devletin kontrolü altında tamamlanması amaçlanmaktadır. Yoksulluğun radikal bir soruna ayaktakımı vasıtasıyla dönüşmesinden hareketle, çözümün temelinde korporasyonların modernizasyonu ve eğitim sisteminde gerçekleştirilecek reform yer almakta, bu sayede bireylerin işgücü piyasasında tutunmaları ve ayaktakımına dönüşmelerinin engellenmesi planlanmaktadır. Modelde bireyler günümüzde de kullanılmakta olan asgari ücret, evrensel gelir desteği gibi iktisadi unsurlarla koruma altına alınmaktadır.
\end{abstract}

Anahtar Kelimeler: Hegel, sivil toplum, yoksulluk, ayaktakımı, korporasyon. 


\title{
The Possibility of a Solution Immanent to Hegel's Philosophical System to the Problem of Poverty
}

\begin{abstract}
Hegel considers the problem of poverty as a problem specific to civil society in the transition to the state stage, and argues that it turns into a radical problem with the rabble, which is a mass that has lost its dignity, respect for the law and self-confidence. Although various solutions were suggested by Hegel to the problem of poverty, many studies found these suggestions insufficient or it is stated that Hegel left the problem unsolved. In this study, a corporation-based solution proposal is brought to the problem of poverty without leaving the boundaries of Hegel's system of thought. In this context, a gradual solution is foreseen for poverty that does not involve direct state intervention or the formation of a full welfare state, and it is aimed that the solution be realized at the civil society stage and completed under the control of the state. Since poverty becomes a radical problem through its transformation into the rabble, the solution lies in the modernization of corporations and the reform to be made in the education system. In the model, individuals are protected by economic factors such as minimum wage and universal income support, which are still used in the modern world.
\end{abstract}

Keywords: Hegel, civil society, poverty, rabble, Corporation.

Corresponding Author / Sorumlu Yazar

E-mail / E-posta

Manuscript Received / Gönderim Tarihi

Revised Manuscript Accepted / Kabul Tarihi

To Cite This Article / Kaynak Göster
Seda Akay Atasoy

Hacettepe University, Department of Philosophy, PhD

Candidate.

ades.karub@gmail.com

October 31, 2021 / 31 Ekim 2021

December 27, 2021 / 21 Aralık 2021

Akay Atasoy, S. (2021). Yoksulluk Sorunu İçin Hegel'in

Sistemine İçkin Bir Çözümün İmkânı, ViraVerita E-Journal: Interdisciplinary Encounters, Vol. 14, 7-38. 


\section{Yoksulluk Sorunu İçin Hegel’in Sistemine İçkin Bir Çözümün İmkânı'}

\section{Giriş}

Toplumun mevcut standartlarının altında ve mevcut avantajlarından mahrum kalması olarak ifade edebileceğimiz yoksulluk, yalnızca birtakım fiziki şartlardan yoksun olmayı değil, aynı zamanda sosyal ve politik yoksunluğu da içeren bir durumu imlemektedir. Bu açıdan yoksulluk siyasi, ekonomik, toplumsal ve felsefi bir sorun olarak karşımıza çıkmaktadır.

Geremek, Orta Çağ’ı yoksulluğun tarihinde başlangıç noktası olarak göstermekte, fakat bu dönemdeki yoksulluğun "Tanrı lütfu" olarak değerlendirildiğini ve bir kabullenişi içerdiğini vurgulamaktadır (Geremek, 1994, s. 17). Yoksulluğun toplumsal bir sorun olarak dinamik bir içerik kazanmasının Orta Çă̆’ın sonlarında başlayan ve özellikle Sanayi Devrimi ile yaşanan ekonomik ve toplumsal dönüşümlerle gerçekleştiği görülmektedir. Yoksulluk, felsefe tarihinde de sıkça incelenen bir konu olmuştur. Platon Devlet adlı eserinde yoksulluğu "iş gören insanı iş görmez hale getiren" felsefi bir sorun olarak ele alırken (Platon, 2002, s. 101 §422a), Aristoteles yoksulluğu bir sorun olarak görmekte ve Politika adlı eserinde yoksullara yapılacak yardımlarla bu kişilerin ticaret ve çiftçiliğe başlamalarının desteklenmesine yönelik bir çözüm önerisi ortaya koymaktadır (Aristoteles, 1998, s. 39 §1265b). Soruna liberalizmin bireysel hak ve özgürlük ilkesi çerçevesinde yaklaşan Locke An Essay on the Poor Law adlı eserinde sorunun tespitinden ziyade sorunun çözümüne yönelmektedir. Bu çerçevede Locke, yoksulluk sorununun çözümünde "çalışma" ilkesini merkeze almakta; yoksullara eğitim ve iş imkânı sağlayacak korporasyonları temel alan bir çözüm öne sürmektedir (Locke, 1997, s. 183). 18. yüzyıl aydınlanmasının önemli isimlerinden biri olan Kant ise, Ingilizceye The Metaphysics of Morals olarak çevrilen eserinde yoksulluğun çözümü noktasında zengin vatandaşlara yönelik bir vergilendirme uygulamasını önermektedir (Kant, 1991, s. 136). 19. yüzyılda ise yoksulluk sorununun nedenlerine ve çözüm yollarına ilişkin tartışmanın kapitalizme ilişkin eleştirilerin odak noktası haline geldiği görülmektedir. Özellikle Hegel'in sivil topluma ilişkin tespitleri ve Marx'ın kapitalizm eleştirisindeki yabancılaşma sorununa ilişkin analizleri çerçevesinde yoksulluğun bu yüzyılda modern burjuva toplumunun bir sonucu ve sorunu olarak değerlendirildiğini söylemek mümkündür.

Bu çalışmada, yoksulluk sorununa ilişkin Hegel'in Hukuk Felsefesinin IIkeleri adlı eserindeki tespitleri ve çözüm önerileri merkeze alınarak söz konusu soruna ilişkin Hegel'in felsefi sistemine içkin olası bir çözümün imkânı ele alınmaktadır. Bu çerçevede ilk olarak Hegel'in 
soruna yönelik tespitleri ve çözüm önerilerine yer verilmekte ve "sivil toplum anlayışı" tinin kendini gerçekleştirme sürecinin bir aşaması olan "törellik" (Sittlichkeit) aşamasının diyalektik bütünselliği çerçevesinde ele alınmaktadır. Daha sonra, alternatif çözüm önerilerine yönelik literatürdeki tartışma Marksist, refah devleti ve korporasyon temelli görüşler çerçevesinde incelenmektedir. Bu bağlamda, yoksulluk sorununun çözümüne ilişkin Marksist temelli görüşlerden Avineri'nin "sivil toplumdan vazgeçiş önerisi” ile Ruda'nın "proletaryan eylem teorisi" esas alınmakta ve bu görüşler çerçevesinde Hegel'in çözüm önerilerine yönelik eleştirel bir bakış ortaya konmaktadır. Refah devleti temelli çözüm önerilerinde Plant'in "reformist refah devleti önerisi" incelenirken, korporasyon temelli görüşler çerçevesinde de literatürdeki güncel tartışma ele alınmaktadır. Son olarak, alternatif çözüm önerilerine ilişkin değerlendirmeler ışığında yoksulluk sorununa Hegel'in sistemine içkin olası bir çözümün imkanının değerlendirilmesi yapılmaktadır.

\section{Özgürlüğün Gerçekleşme Sürecinde Törellik (Sittlichkeit)}

Hegel'in felsefi sisteminde hakikatin bilgisi kendi içinde dinamik olan bir sürecin bütünselliğinde ortaya çıkmaktadır. Bu dinamik bütünsellik tinin kendini gerçekleştirme aşamalarının her birinde ortaya çıkmakta ve tin bütün tamamlandığında kendini gerçekleştirmektedir. Hegel'e göre bütünün ortaya çıkma sürecindeki oluş ve devinim tinin hareketli yapısından kaynaklanmaktadır. Bu durum Hegel tarafından "tin kendi varoluşuna ve düşünme biçimine ilişkin önceki dünya ile bağını koparmıştır, şimdi onların geçmişe çekilmelerine izin veren ve kendini yeniden şekillendiren bir tin olarak kendisini göstermektedir" (Hegel, 2018, s. 8-9) şeklinde ifade edilmektedir. Hegel ayrıca, tinin kendisini gerçekleştirdiği süreçteki hareketinin diyalektik ile sağlandığını ifade etmekte, hakikatin ise diyalektik ilerleyişte bir açılma olarak açığa çıktığını vurgulamaktadır (Türkyılmaz 2015, 119). Dolayısıyla süreç saf bir özdeşlik süreci olmaktan ziyade tinin kendini yeniden kurduğu ve kendini tanıdığı bir süreci ifade etmektedir. Hegel süreçteki devinimde kapsayarak aşmayı ve olumsuzlamanın olumsuzlamasını (Negation der Negation) bütünün tamamlanmasındaki en önemli aşama olarak görmektedir. Ona göre başlangıçta kendinde olan (Ansichsein) olarak yalnızca bir potansiyel halde bulunan tin, doğa alanında kendine yabancılaşmakta ve kendi dışında ötekileşmektedir (Anderssein). Bu aşamada gerçekleşen olumsuzlama, yani kendisini kendi karşıtında gören tinin yabancılaşması, olumsuzlamanın olumsuzlaması ile yani mutlak olumlama (Affirmation) ile aşılmaktadır (Türkyılmaz,2008, s. 275). Hegel'e göre kendinde ve kendi için ide olarak tin öznel tin 
(subjektiver Geist), nesnel tin (objektiver Geist) ve mutlak tin (absoluter Geist) aşamalarının diyalektik süreci tamamlandığında öz bilincine ulaşmakta ve kendini gerçekleştirmektedir. Sistemin sentez aşaması olan bu bütünselliğin tamamlanması ile tin, geçtiği süreçlerin farkına vararak ve tüm karşıtlarını kapsayıp aşarak kendine dönüşünü tamamlamakta ve hakikat ortaya çıkmaktadır. Hegel tinin kendi bilincine ulaşması olan bu süreci aynı zamanda özgürlüğünün bilincine varma süreci olarak ortaya koymaktadır.

Hegel, Hukuk Felsefesinin Ilkeleri adlı eserinde bilincin gelişim sürecindeki bütünselliği nesnel tin aşamasının soyut hukuk (abstrakte Recht), ahlak (Moralitaet) ve törellik (Sittlichkeit) aşamaları ile ele almaktadır. Ona göre özgür iradenin merkezde olduğu nesnel tin aşaması, hukukun alanı olarak öznel tinin kendini nesne edindiği, diğer özgür iradeleri tanıdığı ve yaşamı belirleyen kurallar sisteminin başladığı bir aşamaya karşılık gelmektedir. Bu nedenle Hegel hukuk sistemini gerçekleşmiş bir özgürlük alanı olarak görmektedir (Hegel, 1991, s. 40). Hegel'in sivil topluma ilişkin görüşleri bu gelişim aşamalarından törellik (Sittlichkeit) aşamasında ortaya konulmakta ve bu aşamada özgürlük sivil toplumun aşılması ile geçilecek olan devlette gerçekleşmektedir. Bu çerçevede Hegel törelliği (Sittlichkeit) "gerçek dünya haline, kendilik bilincinin tabiatı haline gelmiş özgürlük kavramı” olarak tanımlamaktadır (Hegel, 1991, s. 144).

Hegel törellliğin (Sittlichkeit) ilk aşamasına sevgi ve duygu ile betimlediği aileyi yerleştirmekte ve bu aşamadaki diyalektik bütünselliğin evlenme, ailenin mülkiyeti ve çocukların eğitimi ve dağılması ile tamamlandığını belirtmektedir. Hegel'in "ailenin duygusal birliğini sağlayacak dolaysız bir ahlaki olay" olarak betimlediği evlilikte cinsel birliktelik tinsel bir sevgi birlikteliğine dönüşmektedir (Hegel, 1991, s. 146). Bu dönüşümle sevgi ve güven temelli bir paylaşım ilişkisi de başlamaktadır. Ailenin edimselliğinin mülkiyetle gerçekleşeceğini belirten Hegel söz konusu mülkiyetin bireysel bir mülkiyetten ziyade ortak mülkiyete ilişkin olduğunu ifade etmektedir (Hegel, 1991, s. 152). Ailedeki duygusal birlik çocukların özel şahsiyetler olarak yetiştirilmesi ve çocuğa yönelik sevgi ile kendini göstermekte, özel şahsiyetler olan çocukların çoğalması ile aile bölünerek dağılmakta ve dış ilişkiler süreci başlamaktadır. Bu noktada aile aşamasından dış ilişkilerin somut intiyaçlar olarak şekillendiği ve bu ihtiyaçların tatmininin gerçekleştiği sivil toplum alanına geçilmektedir. Hegel sivil toplum alanını özel şahsın başka şahıslarla ilişki içerisinde olduğu ve kendisini başkası aracılığıyla ortaya koyup tatmin ettiği bir alan olarak betimlenmektedir (Hegel, 1991, s. 159). Temelde Hegel sivil toplum alanı ile burjuva toplumunu imlemekte ve bu alanın öznesini ise bürger veya bourgeois olarak ifade ettiği kent soylusu, burjuva olarak adlandırmaktadır (Hegel, 1991, s. 165). 
Hegel'e göre sivil toplumda çıkar ilişkilerinin şekillendirdiği tikellik tümel ve evrensel olanı araçsallaştırmaktadır (Hegel, 1991, s. 162). Bu çerçevede Hegel sivil toplumu ihtiyaçlar sistemi ile açıklamakta, sistemin merkezine ise emek ve faaliyeti yerleştirmektedir. İhtiyaçları ise doğal ve sosyal ihtiyaçlar olarak ikiye ayıran Hegel, sosyal ihtiyaçların tatmininin doğal ihtiyaçların dolaysız tatmininden farklı olduğunu belirtmekte ve emeği öz bilincin gelişimi ve özgürlük için önemli bir aşama olarak görmektedir (Hegel, 1991, s. 166). Nitekim Hegel'e göre insan emek sayesinde yalnızca nesneleri dönüştürmemekte, aynı zamanda nesneye kendisinden bir şeyler katmaktadır. Hegel emeğin özgürleşme sürecindeki önemini efendi-köle diyalektiği çerçevesinde ele aldığı ötekinin dolayımından geçerek kendini gerçekleştirme süreci olan tanınma süreci ile ilişkilendirmektedir. Ona göre çalışma tanınma sürecinde özgürleşmenin önemli bir dolayımı olmakta ve kişiler kendilerini ve özgürlüklerini bu tanınma sürecinde eylemleriyle gerçekleştirmektedirler (Türkyılmaz, 2016, s. 139). İhtiyaçlar sistemi içerisinde farklı ihtiyaçların tatmini işbölümünü doğurmakta ve işbölümü insanları birbirine karşılıklı olarak bağımlı hale getirmektedir. Hegel'e göre bu karşılıklı bağımlılık emeği mekanikleştirmektedir. Hegel bu durumu "bir insanın üretiminin öteki insanların üretiminden soyutlanması emeği gittikçe daha çok mekanikleştirir, öyle ki, sonunda, insanın emeği dışlayıp kendi yerine makinaları koyması imkân dâhiline girer" şeklinde ifade etmektedir (Hegel, 1991, s. 168). İhtiyaç ve emek ilişkisinde ortaya çıkan bu karşılıklı bağımlılık kişinin yalnızca kendisi için üretip kazanmadığı aynı zamanda tüm bunları diğeri içerisinde gerçekleştirdiği bir sistemi ortaya çıkartmaktadır. Ancak temel amaç bireyin kendi gereksinimlerini karşılaması olduğundan sivil toplumda sürekli olarak evrensel tikele geri dönülmektedir (Savran, 2013, s. 202).

Hegel bireyi, ihtiyaçlarını gidermesi için kendi olanaklarına bağımlı kılan sivil toplumun bir çocuğu olarak görmekte ve sivil toplum ile birey arasında karşılıklı bir ilişki olduğunu belirtmektedir (Hegel 1991: 190). Bu karşılıklı ilişkiyi intiyaçlar sistemi, yargı gücü ve kamu yönetimi ve korporasyon çerçevesinde ele almaktadır. Hegel'e göre sivil toplum toplu öğretim kurumları açarak kişilerin savurganlıkları sonucunda içine düşecekleri savurganlığın beraberinde getireceği geçim sıkıntılarını güvence altına alabilmektedir (Hegel, 1991, s. 190-191). Hegel'e göre sivil toplum içerisinde bireylerin mülkiyet ve şahsiyet gibi hakları yargı gücü ile güvence altına alınırken, geçimlerine ve refahlarına ilişkin hakları kamu yönetimi ve düzenlemeleri ile korunmaktadır (Hegel, 1991, s. 187). Hegel'e göre kamu yönetiminin kurumlarıyla bireysel çıkarların kitlesel güvenliği sağlanmaya çalışılsa da sivil toplum içerisindeki tikellik tam olarak aşılamamaktadır. Ona göre özel çıkarların şekillendiği bencil amaçlar korporasyon içinde 
evrensel bir gayeye dönüşmektedir (Hegel, 1991, s. 196). Bu çerçevede Hegel korporasyonları ikinci bir aile gibi ele almakta ve devlet aşamasına geçişte önemli yönlendirici kurumlar olarak görmektedir. Hegel sivil toplumdan devlet aşamasına geçişte korporasyonların önemini "korporasyon esprisi [tini], özelin evrensele köklü bağlılığını kendi özüne dolaysızca içerir; bunun için devletin kalplerde uyandırdığı derin ve güçlü duyguların kaynağı bu korporasyon esprisidir [tinidir]" şeklinde dile getirmektedir (Hegel, 1991, s. 237). Aynı zamanda Hegel korporasyonları sivil toplumun içsel bir ürünü olarak ortaya çıkan yoksulluk sorununun çözümü için bir çıkış kapısı olarak görmektedir.

Hegel, sivil toplumun kapsanıp aşılmasıyla geçilecek olan son aşama olan devlette edimselliğin gerçekleşerek evrenselliğin ve özgürlüğün açığa çıkacağını belirtmektedir. Hegel devleti "objektif ahlak idesinin fiil halindeki realitesidir-kendi kendisine açıkça görünen, kendi kendisini bilen ve düşünen ve bildiğini, bildiği için yapan cevhersel irade olarak ahlaki espridir [tindir]" şeklinde açıklamaktadır (Hegel, 1991, s. 199). Hegel'e göre tikel irade ile tümel iradenin birliği devlette tam bir birlik haline gelmektedir. Sivil toplumun bireysel çıkarlarının her şeyi ve herkesi birbiri için araçsallaştırmasının aksine devlette herkes herkes için amaç olmakta ve özgürlük somutlaşmaktadır. Hegel, törelliğin (Sittlichkeit) en yüksek aşaması olan devlet idesinin gelişim aşamalarını ise siyasi ana yapı, uluslararası hukuk ve evrensel tarih süreci ile ortaya koymaktadır (Hegel, 1991, s. 202). Hegel iç siyasi hukuku devletin yasama, yürütme ve hükümranlık gücü ile açıklamakta ve anayasal monarşiyi özgürlüğün açığa çıkabileceği bir sistem olarak görmektedir (Hegel, 1991, s. 225). Hegel devletin edimselleşmesinin uluslararası hukuk aşamasında diğer devletlerle olan ilişkilerle gerçekleştiğini belirtmekte (Hegel, 1991, s. 262) ve devletlerin dünya tarihi sahnesinde bu ilişkiler ağı ile tinin kendini gerçekleştirmesine uygun rolleri onadıklarını belirtmektedir. Hegel'e göre evrensel tin evrensel tarihte ulusal tinlerle somutlaşmaktadır (Hegel, 1991, s. 266). Hegel ulusal tinleri evrensel tinin özgürleşmesinin, kendini gerçekleştirmesinin ve kendi bilincine ulaşmasının aşamaları olarak görmekte ve tinin tarihteki özgürleşme sürecini evrensel tarihin doğu dünyasından Germen dünyasına doğru ilerleyişi ile açıklamaktadır.

\section{Sivil Toplumun İçsel Bir Sorunu Olarak Yoksulluk Sorunu ve Hegel'in Çözüm Önerileri}

Hegel'in sivil topluma ve ihtiyaçlar sistemine ilişkin analizlerinde klasik iktisat kuramcılarından Adam Smith'in ticari toplum düzenine ilişkin görüşlerinin etkisi görülmektedir. Smith, emek ve iş bölümünü karşıııklı ilişkileri çerçevesinde sermaye ve ekonomik büyüme için zorunlu iki unsur 
olarak görmekte (Smith, 2008, s. 5); iş bölümü ve emek arasındaki karşılıklılığın sonucu olarak kişinin kendi çıkarları için çalışırken aynı zamanda genel çıkara hizmet ederek genel refahı da arttırdığını savunmaktadır (Smith, 2008, s. 33). Hegel ve Smith'in analizleri pek çok açıdan benzerlik taşımakla birlikte sivil toplumun bir sorunu olan yoksulluk sorununa yaklaşımları birbirinden farklılaşmaktadır. Smith'e göre yoksulluk kişilerin zengin gibi yaşama hedef nedeniyle ortaya çıkmaktadır (Smith, 2018, s. 94). İşçi temel ihtiyaçlarını gidermesi için yeterli olanı kazanmasına karşın erişemeyeceği bir yaşamı istemekte, bu durum işçiyi utanma duygusunun beraberinde getireceği zihinsel bir acıya sürüklemekte, bu duygu ise giderek zengine yönelik bir öfkeye dönüşmektedir (Smith, 2018, s. 76-77). Smith ciddi bir sorun olarak görmediği yoksulluğa ilişkin açık bir çözüm önerisi de ortaya koymamaktadır. Nitekim Smith "görünmez el" kuramı çerçevesinde piyasa dengelerinde ortaya çıkacak olan bozulmanın bir müdahaleye gerek kalmaksızın düzeleceğini belirtmekte, ekonomik daralma dönemlerinde artacak yoksulluğun ekonomik toparlanma ile herhangi bir müdahale olmaksızın gerileyeceğini ifade etmektedir. Smith'e göre ekonomik aktörler kendi çıkarlarının peşinden koşarken aynı zamanda toplumun refahına da katkıda bulunmaktadır. (Smith, 2008, s. 485). Yoksulluğu azaltmak için yardım temelli bir çözüm arayışı ise toplumsal düzen ve adalet açısından ahlaki olarak kusurlu bir duygudaşlık yaratacaktır (Smith, 2018, s. 328). Smith, ekonomiye devlet müdahalesinin; savunma, hukuk, altyapı gibi alanlarla sınırlı kalması gerektiğini vurgulamaktadır. Diğer taraftan, bu sınırlandırma Hegel'in devlet anlayışına uygun değildir. Hegel liberalizmdeki en temel yanlışı bireylerin yalnızca yaşamlarını, özgürlüklerini ve mülklerini koruma işinin devlete bırakılmasında görmektedir (Bravo, 2006, s. 112). Böylesi bir anlayış Hegel'e göre devleti araçsallaştırmaktadır. Oysa Hegel'e göre özgürlük ve düşüncenin evrenselliği devlette gerçekleşmekte, hak ve görev devlette bir birlik halini almaktadır.

Aynı zamanda Hegel, Smith'in aksine, yoksulluk sorununu sivil toplumun kaçınılmaz ve ciddi bir sonucu olarak değerlendirmekte ve yoksulluğu, "hareketlerinde serbest bırakıldığında, sivil toplumun sanayi ve nüfus içindeki ağırlığı artar. İnsan ilişkilerinin insan isteklerine ve bu isteklerin karşılanmasının yollarına bağlı olarak genellenmesiyle büyük bir servet birikimi olur" (Hegel, 2001, s. 188) ifadesi ile dile getirmiş olduğu servet birikimindeki hızı artış ile ilişkilendirmektedir. Hegel'e göre sivil toplumdaki servet birikiminin aşırılığı hem zengin hem de yoksul için toplumun olanaklarından mahrum kalmanın beraberinde getirdiği yıkıcı bir zihniyeti ortaya çıkarmaktadır. 
Hegel'e göre söz konusu mahrumiyetin yaratmış olduğu yıkıcı zihniyet devlet ile gerçekleşecek olan bütünleşme için tehlike oluşturmaktadır. Buna göre yoksulun yoksunluğu sonucunda yaşadığı duyarsızlaşma devlete ve zengine dönük bir isyanı ortaya çıkaracaktır (Hegel, 2001, s. 188). Yoksulluğun böylesi bir zihin durumuna dönüşmesi Hegel'e göre uzlaşmadan, evrenselden ve bütünden kopuk ayaktakımını (Pöbel) ortaya çıkarmakta, yoksulluk sorunu ise ayaktakımı sorununa dönüştürmektedir. Hegel yoksulların ayaktakımına dönüşmesini "geniş bir kitle, asgari geçim düzeyinin bir toplumun üyesi için zorunlu olan ve kendiliğinden ayarlanan düzeyin altına düştüğü ve böylece, kendi öz faaliyeti ve öz emeği ile yaşamak onurunu, hak, hukuk ve kendi güven duygusunu kaybettiği zaman ortaya bir pleb yığını çıktığı görülür" (Hegel, 1991, s. 192) ifadeleri ile açıklamaktadır. Bu çerçevede yoksulluğun kaçınılmaz ve ciddi bir sorun olarak değerlendirilmesini ve çözümünün gerekliliğini sorunun ayaktakımı sorununa dönüşümünün beraberinde getirdiği zorunlulukta görmektedir.

Hegel yoksulluk sorununun çözümünde yoksulluğun öznel durumlarından hareketle öznel yardımları ele almakta; yardımın etkilerinin geçici olacağını, yapılması gerekenin yoksulluk için genel bir çözüm keşfedilerek yardımların sistematik hale getirilmesi olduğunu belirtmektedir (Hegel, 2001, s. 188). Benzer şekilde Hegel, yoksulların kamu hizmetlerinden (hastaneler, vakıflar ya da sandıklar gibi) doğrudan destek almalarının da bir çıkış gibi görülebileceğini belirtmekte ancak bu durumun geçiciliğini ve sivil toplumun iç dinamiğine aykırılığını "yoksullar kamu hizmetlerinden doğrudan destek alabilirlerse, herhangi bir iş yapmaya gerek kalmadan geçimlerini sağlayabileceklerinden emin olurlar. Bu düzen hem sivil toplumun ilkelerine hem de üyelerinin bağımsızlık ve onur duygusuna sahip olmalarına aykırı olacaktır" (Hegel, 2001, s. 189) şeklinde ifade etmektedir. Dolayısıyla Hegel'e göre dışsal yardımlar bireyi sivil toplumun temel ilkesi olan çalışmadan uzaklaştırmakta ve sistem içerisinde atıl konuma itmektedir. Yoksullara doğrudan yardım yapmak yerine bu kişilere çalışma fırsatı verilerek sistem içinde atıl duruma gelmelerinin önlenmesini içeren bir çözüm önerisi ise aşırı artan üretim ve beraberinde gelecek yoksulluk nedeniyle sorunun çözümünde eksik kalmaktadır (Hegel, 2001, s. 189).

Kolonileşmeyi de bir başka çözüm önerisi olarak ele alan Hegel, bu öneriyi "yeni topraklarda, nüfusun bir kısmı için aile ilkesine geri dönüş imkânı; sivil toplum için de yeniden üretimin teşviki ve çalışma alanı oluşur" şeklinde ifade etmektedir (Hegel, 2001, s. 190). Ancak Hegel'e göre bu öneri üretim fazlasının yaratacağı yoksulluk için yeni pazarların oluşturulmasını esas almakta, böylesi pazarların oluşturulması ise yoksulların başka ülkelere transfer edilmesi 
sonucunda sorunu kolonilere taşımanın ötesine geçmemektedir. Dolayısıyla koloni vasıtasıyla yoksulluk sorunu yalnızca geçici bir süre için baskılanmaktadır.

Hegel çözüm önerilerine ilişkin yapmış olduğu bu analizler çerçevesinde hareketlerinde serbest bırakılan sivil toplumun içsel bir sorunu olarak ortaya çıkan yoksulluk sorununun öznel yardımlar, kamu hizmetlerinden doğrudan destek alımını içeren dışsal yardımlar, yeni çalışma imkanlarının sağlanması ve kolonileşme çerçevesinde köktenci bir çözüme kavuşmadığını belirtmektedir. Hegel'e göre yoksulluk sorununun merkezinde servet birikimindeki orantısız artış yer aldığından ortaya konulacak olan çözüm önerisinin köktenci bir çözümü içermesi için servet birikimindeki bu orantısız artışı kontrol altına alması gerekmektedir. Hegel, bu çerçevede yoksulluk sorununa devlet aşamasına geçişte bir köprü olarak konumlandırdığı korporasyonlarla çözüm kapısı aralamaktadır. Hegel etik bir öğe olarak betimlediği korporasyonlarda kendi çıkarlarını gözetme duygusunun evrensel bir hal aldığını ve sivil toplumun her üyesinin özel yetenekleri ile korporasyonların bir üyesi olduğunu ifade etmektedir (Hegel, 2001, s. 191). Buna göre, tıpkı bir ailede olduğu gibi, korporasyonlarda da bireyin geçimini sağlaması güvence altına alınmaktadır. Hegel, korporasyonların yoksulluk sorununa olan etkisini, korporasyonlarda yoksulların aldığı yardımın yoksulları düşürdüğü haksız konumu ve buna bağlı olarak ortaya çıkan aşağılanmayı ortadan kaldırmasında görmektedir (Hegel, 2001, s. 192).

\section{Yoksulluk Sorununa Marksizm Temelli Alternatif Çözüm Önerileri}

Marx yoksulluk sorununu, modern burjuva toplumunda ortaya çıkan yabancılaşma sorunu çerçevesinde ele almakta ve sorunun çözümünü sınıflı toplum yapısının ortadan kaldırılmasında, "büyük çoğunluğun, büyük çoğunluk çıkarına olan öz bilinçli, bağımsız hareketi" olarak ifade ettiği proletaryan harekette görmektedir (Marx ve Engels, 2005, s. 129). Marx çıkar ilişkilerinin merkezde olduğu modern burjuva toplumunda üretim güçleri ve üretim ilişkileri arasındaki dengenin üretim güçlerinin lehine bozulması sonucunda ortaya çıktığını savunduğu yoksulluğu ise servet artışına paralel olarak şekillenen sınıfsal ayrımlar çerçevesinde ele almaktadır. Modern burjuva toplumunun özsel bir niteliği olarak gördüğü bu sınıfsal ayrımın toplumda para dışında her şeyin değersizleştiği, yoksullaşma ve yabancılaşma ile görünür hale gelen bir toplumsal çözülme olarak değerlendirmektedir. Bu çerçevede Marx modern burjuva toplumunu "kişisel değeri, değişim değerine dönüştürdü ve sayısız yok edilmez ayrıcalıklı özgürlüklerin yerine, o biricik insafsız özgürlüğü, ticaret özgürlüğünü koydu. Tek sözcükle dinsel ve siyasal yanılsamalarla maskelenmiş sömürünün yerine, açık utanmaz, dolaysız, kaba 
sömürüyü koydu" (Marx ve Engels, 2005, s. 119) ifadeleriyle eleştirmektedir. Ona göre servet artışı burjuvanın zenginliğini arttırırken, işçiyi yaşamak içinde çalışmaya mecbur olan ücretli bir köleye dönüştürmekte ve işçi emeğine yabancılaşmaktadır. Marx’a göre, artık emek kendisini üretenden bağımsızlaşmaktadır. Bu durum ise işi emek ürününe yabancılaştırarak "işçinin gerçekliğinin yok olmasına" neden olmakta (Marx, 2005, s. 75) ve "işçinin nesneye aktardığı hayat, yabancı ve düşmanca bir şey olarak kendi karşısına çıkmaktadır" (Marx, 2005, s. 76). Marx, emeğin ürününe yabancılaşmayı "işçinin üretimi ne kadar çoksa tüketimi de o kadar azdır, ne kadar çok değer yaratırsa, kendisi o kadar değersizleşir, ürünü ne kadar biçimliyse, iş̧̧i kendisi o kadar biçimsizdir; nesnesi ne kadar uygarsa, işçi o kadar barbardır; emek güçlendikçe işçi güçsüzleşir; emek akıllandıkça iş̧̧i ahmaklaşır ve doğaya köle olur" (Marx, 2005, s.77) ifadeleriyle açıklamaktadır. Marx’a göre yabancılaşma yalnızca üretimin sonucunda değil, üretim sürecinde de kendisini göstermekte ve çalışma işçi için sorunlu bir eyleme dönüşmektedir. Marx bu süreci ve ortaya çıkacak olan emek edimine yabancılaşmayı "işin iş̧̧iye değil başka birine ait olması, işçinin çalışırken kendine değil başka birine ait olması" (Marx, 2005, s. 78) ile açıklamaktadır.

Marx, çalışmayı insanı hayvandan ayıran türsel bir özellik olarak ele almakta ve bu ayırıcı özelliği bilinçli bir eylem olarak görmektedir (Marx 2004:181). Ancak Marx'a göre işçi emeğine yabancılaşırken aynı zamanda kendi insansal özüne, türüne de yabancılaşmakta ve çalışma zorunlu bir eyleme dönüşmektedir. Marx yabancılaşmanın son görünümünü toplumsal ilişkilerde kontrolün nesnelere geçmesinin beraberinde getirdiği insanın insana yabancılaşması ile açıklamaktadır. Bu durum Marx tarafından "insanın kendi emeğinin ürününden, hayatetkinliğinden, türsel varlığına yabancılaşması olgusunun dolaysız bir sonucu, insanın insana yabancılaşmasıdır. İnsan nasıl kendi kendisiyle karşı karşıya geliyorsa, öteki insanla da karşı karşıya gelmektedir" (Marx, 2005, s. 82-83) biçiminde ifade edilmektedir. Marx’a göre, modern burjuva toplumuna egemen olan kapitalist ekonomide emeğin sermaye birikimi için yalnızca bir üretim faktörü olarak görülmesi emeği bir sömürü aracına dönüştürmektedir. Böylece, modern burjuva toplumunda bir yandan burjuvanın zenginliği artarken, diğer yandan bu zenginliğin artmasında emeğiyle mevcudiyet gösteren proletaryanın yoksulluğu artmaktadır. Marx, emeğin nesneleşmesi sonucunda oluşacak olan yabancılaşmayı ve yoksullaşmayı "işçi ne kadar çok servet üretse, üretimin gücü ve kapsamı ne kadar artsa, kendisi de o kadar yoksullaşır. Ne kadar çok meta yaratırsa kendisi de bir meta olarak o kadar ucuzlar. Şeyler dünyasının artan değeriyle doğrudan doğruya orantılı olarak insanlar dünyası değersizleşir. Emek yalnız meta üretmez; 
kendini ve bir meta olarak işçiyi de üretir- ve bunu meta ürettiği oranda gerçekleştirir" (Marx, 2005, s. 75) ifadeleriyle açıklamaktadır. Marx toplumun refahını arttırma amacı ile emek, iş bölümü ve sermaye arasında kurulan ilişkinin işçiyi "çalışan bir hayvan" statüsüne yerleştirdiğini ifade etmekte ve "proleter'in, yani sermayesi ve rantı olmayan, yalnızca emeğiyle yaşayan ve tek-yanlı, soyut emeğiyle yaşayan adamın politik iktisat tarafından yalnızca işçi olarak düşünüldüğünü" (Marx, 2005, s. 25) belirtmektedir.

Marksist ekole mensup düşünürlerden Shlomo Avineri, Hegel'in sivil toplum anlayışını Hegel's Theory of the Modern State eserinde Marx'ın yabancılaşma görüşü çerçevesinde ele almaktadır. Avineri öncelikli olarak Hegel'in emek kavramına yaklaşımını ele almakta ve emeğin tanınma ilişkisinin merkezine yerleştirilmesiyle emeğin toplumsal bir içerik kazanarak toplumsal emeğe dönüştüğünü ifade etmektedir (Avineri, 1972, s. 88). Emeğin dolayımının beraberinde bir bağımlılık getireceğini ve bunun üretim anlayışında bir soruna neden olarak birey ve bireyin ihtiyaçları arasındaki bağı koparacağını savunan Avineri sorunu "insanlar kendi spesifik ihtiyaç duydukları nesneleri üretmezler, bunun yerine ihtiyaç duydukları nesneler ve somut nesneler için takas yapmada kullanacakları genel ürünler üretirler" (Avineri, 1972, s.91) ifadeleriyle açıklamaktadır. Bu çerçevede Avineri toplumsal emekle birlikte ortaya çıkacak olan karşııklıı̆̆ın yaratacağı sorunu üretimin kendisinde ortaya çıkacak olan bir yabancılaşma sorunu olarak görmektedir.

Avineri yoksulluğu "sivil toplumun yarattığı ihtiyaçlar ve bu ihtiyaçların karşılanamaması arasındaki gerilimin ifadesi olan diyalektik bir kavram" (Avineri, 1972, s. 149) olarak açıklamaktadır. Avineri'ye göre sivil toplumda sürekli yeni ihtiyaçlar ve arzular üretilmekte ve yoksulluk sivil toplumun bir sorunu haline gelmektedir. Avineri için yoksulluk niceliksel bir yoksunluğun ötesinde sivil toplumun bütünleştirici kurumlarının niteliksel içeriğindeki yoksunluğu da içermektedir (Avineri, 1972, s. 150). Avineri bu niteliksel yoksunluk noktasında Hegel'in mülkiyet ve kişilik arasında kurmuş olduğu ilişkiyi ele almaktadır. Hegel mülkiyeti kişiliğin vücut bulmuş hali olarak betimlerken (Hegel, 1991, s. 68), Avineri'ye göre Hegel'in mülkiyet ve kişilik arasında kurmuş olduğu bu ilişkide niteliksel yoksunluk yoksulların kişiliklerinden mahrumiyetini de ifade etmektedir.

Avineri, sivil toplum alanını "bireylerin diğer herkese kendi amaçları için bir araç olarak davrandığı bir evrensel egoizm alanı" olarak tanımlamakta ve bu alanı ihtiyaçların sürekli artmasına ve çeşitlenmesine bağlı olarak ortaya çıkan yabancılaşma sorunu çerçevesinde ele almaktadır (Avineri, 1972, s. 134). Ona göre yoksulluk sorununa ilişkin Hegel'in tespitleri sivil 
toplum için radikal bir eleştiri niteliği taşımakta ancak bu radikallik Hegel'in ortaya koymuş olduğu çözümlerde korunamamaktadır. Avineri Hegel'in yoksulluk sorununu çözüm noktasında eksik bırakmasını içinde bulunduğu bir ikilemin sonucu olarak görmektedir. Avineri bu ikilemi "eğer devleti ekonomik etkinliğin dışında bırakırsa, sivil toplumun üyelerinin büyük bir kısmı bunun dışında kalacaktır; ancak devleti sorunu çözecek bir şekilde devreye sokacak olursa, bu durumda sivil toplum ve devlet arasında yaptığı ayrım ortadan kalkacak ve ayrımlaşma yoluyla bütünleşmeye dönük dolayım ve diyalektik ilerlemenin tüm sistemi çökecektir" (Avineri, 1972, s.151) şeklinde ifade etmektedir. Bu çerçevede Avineri'ye göre yoksulluk sivil toplumun işlemesindeki bir eksiklikten ziyade iyi işlemesi sonucunda ortaya çıkan bir sorun olduğundan, sorunun çözümü de sorunu ortaya çıkaran sınırlanmamış sivil toplumun gözden çıkarılmasındadır.

Hegel'de yoksulluk sorununun çözümüne ilişkin bir diğer Marksizm temelli görüş Frank Ruda tarafından ortaya konmaktadır. Ruda'nın Ingilizceye Hegel's Rabble: An Investigation into Hegel's Philosophy of Right adıyla çevrilen eserinde yoksulluk sorununa ilişkin analizleri ve Hegel'e yönelik eleştiriler dikkat çekmektedir. Ruda soruna yaklaşımının Avineri'den farklı olduğunu belirtmekte ve bu durumu “Avineri'den farklı olarak, yoksulluğun Hegel'in ayaktakımı adı altında tespit ettiği temel sorunun nasıl gerekli koşulu olduğunu gösterme amacındayım" (Ruda, 2011, s. 4) şeklinde ifade etmektedir.

Ruda bir yandan Hegel'in yapmış olduğu yoksulluk ve ayaktakımı ayrımına değinerek yoksulluktan ayaktakımına geçişin önemli olduğunu vurgulamakta diğer yandan da Hegel'in yoksulluk ile mücadelesini ve çözüm önerilerini eleştirmektedir (Ruda, 2011, s. 10). Ona göre yoksulluk sorunun radikalleşmesi sonucunda ortaya çıkacak olan ayaktakımı sivil toplumun bir problemidir, ancak Hegel tarafından devletin bir problemi olarak değerlendirilmediğinden Hegel'in problemi olamamıştır (Ruda, 2011, s. 99). Bu çerçevede Hegel'in çözüm önerilerini inceleyen Ruda Hegel'in bir çıkış kapısı olarak konumlandırdığı korporasyon önerisinin de diğer öneriler kadar yetersiz kaldığını düşünmektedir. Çünkü Ruda'ya göre korporasyonlar içerisinde yer alacak bireyler özel beceri ve yetenekleri ile korporasyon üyesi olurken bu özellikleri taşımayanlar için sorun varlığını korumaktadır. Bu durumu Ruda, "korporasyonlar bildiği ve gördüğü yoksulları besler, onun dışındakileri içine almaz" (Ruda, 2011, s. 22) ifadeleriyle dile getirmektedir.

Ruda'ya göre sivil toplumun aktif öznesi, çalışma ile ihtiyaçlar sisteminin ilişkiler ağı içerisinde kendi rasyonelliğini gerçekleştirmektedir. Ruda'ya göre bu ilişkiler ağı içerisinde 
ihtiyaçların farklılaşması ve farklılaşan bu ihtiyaçların sürekli tatminin istenmesi bağımlılığı da arttırmaktadır (Ruda, 2011, s. 11). Özne, çalışma ile sivil toplum içerisinde hem toplumun refahını korumakta hem de evrensel olana aracılık yaparak kendini korumaya çalışmaktadır (Ruda, 2011, s. 13). Bu çerçevede, çalışma ilkesi evrensele ulaşma ile bir mal varlığına sahip olmayı özdeşleştirmekte; mal varlığına sahip olmama durumu ise yoksulu bu evrenselden koparmakta, yabancılaşmış, ayrışmış ve çözülmüş bir yığını yani ayaktakımını ortaya çıkartmaktadır. Dolayısıyla yoksulluk, sivil toplum içerisindeki rasyonelliğin ortaya çıkardığı bir irrasyonellik olarak sivil toplumun içsel bir sorunu, bir ürünü olmaktadır (Ruda, 2011, s. 33). Ruda'ya göre sivil toplumun temel ilkesi olarak çalışma, bireyin kendi geçimini sağlamasını esas almakta; ayaktakımı ise geçiminin sağlanması talebinin gerçekleşmemesine karşı bir öfke duyarak evrenselden kopmaktadır (Ruda, 2011, s. 36). Ruda bu noktada yoksulluk sorununun radikalleşerek bir ayaktakımı sorununa dönüşmesini yoksulun öfkesi ile açıklamakta, devlete ve devletin kurumlarına duyulan bu öfkenin yoksulu ayaktakımı yaptığını savunmaktadır. (Ruda, 2011, s. 114). Ayaktakımının geçiminin sağlanması için bulunduğu talep, sivil toplumun içsel yapısından dolayı haksız bir talep olarak görülmektedirii.

Ayaktakımının karakteristik özelliklerini parçalanma, yabancılaşma, çözülme ve ayrımlaşma olarak ifade eden Ruda, Hegel'in de belirttiği üzere, ayaktakımının yalnızca yoksulluk içinde beliren bir durum olmadığını zenginlik içerisinde de ortaya çıkabileceğini vurgulamaktadır. Ona göre yoksul ayaktakımı herkesin sahip olduğu haklardan mahrum bırakıldığını hisseden bir yığın olarak evrenselden koparken zengin ayaktakımı ise kendini bu hakların kaynağı olarak hissederek kendini evrenselin üstünde görmektedir (Ruda, 2011, s. 41). Sonuç olarak her iki ayaktakımı da ahlaki ve yasal bir yozlaşma içerisine girmekte ve yabancılaşmaktadır. Ancak bu çerçevede Ruda zengin ayaktakımının yaşayacağı çözülmeyi serveti konusunda yaşayacağı herhangi bir kayıp sonrasında hukukun sağlayacağı güvenceye bağlı olarak kısmi bir çözülme olarak değerlendirmektedir. Bu kısmi çözülmenin aksine yoksul ayaktakımında haklardan ve görevlerden mutlak bir çözülme ortaya çıkmaktadır (Ruda, 2011, s. 67).

Ruda, Hegel'in "kişi olma” ve "diğer insanlara saygılı olma” kavramlarını hukukun temeline yerleştirmesinden hareketle, yoksul ayaktakımının kişi olma statüsünü başkalarına olan saygısını kaybetmesinden ve hukukun temel zorunluluğundan kendini ayrıştırmasından dolayı kaybettiğini savunmaktadır (Ruda, 2011, s. 66). Hegel'in mülkiyet ve kişilik arasında kurmuş olduğu ilişkinin sonucunda yoksullukta ortaya çıkan mahrumiyetin kişilik mahrumiyetine 
dönüştüğüne ilişkin Avineri'nin eleştirilerine benzer şekilde Ruda da kurulan bu ilişkinin mülkiyet imkânından yoksun olan ayaktakımını haklarından ve görevlerinden uzak, kişi olmadan kopmuş bir yığın durumuna getirdiğini belirtmektedir (Ruda, 2011, s. 128). Kişi olmamak ise özgürlügünün farkına varmamak, özgür olmamak, toplumsal olmamak, hak ve görev sahibi olmamak anlamına gelmektedir.

Ruda ayaktakımının öfkesinin asosyal bir tavır olduğunu belirtmekle birlikte ayaktakımının devletten ve devletin kurumlarından kopuşunun kendi hatasının veya isteğinin bir sonucu olmadığını eklemektedir (Ruda, 2017, s. 174). Bu çerçevede Ruda Hegel'in ayaktakımının evrenselden kopuşunu ahlaki bir kötülük ve negatif bir anlayış olarak değerlendirmesini de eleştirmektedir. Çünkü ona göre ayaktakımının durumu nesnel bir imkânsızlığın içselleştirilmesinin bir ürünü olarak ortaya çıkmaktadır (Ruda, 2011, s. 115). Bu çerçevede ahlaki toplumun içinde ortaya çıkan ancak ahlaki ilişkilerin dışında yer alan ayaktakımının öfkesini Žižek gibi Ruda da haklı ve gerekli bir öfke olarak görmektedir.

Ruda, Hegel'in sistemi içerisinde devletin konumunu, organik bir birleştirici olarak insan yığınlarını (vulgus) ortadan kaldıran ve güçlü bir blok oluşturmalarını engelleyerek devlete karşı gelmelerinin önüne geçen bir birlik olarak açıklamaktadır (Ruda, 2011, s. 149-150). Ayaktakımının kendi içinde bir birliğinin olup olmadığını sorgulayan Ruda'ya göre Hegel'in yapmış olduğu ayrımlar çerçevesinde birlik sahibi olan insan gruplarını (populus) yığınlardan (mass) ayıran en temel fark mülkiyet sahibi olup olmama durumunda açığa çıkmaktadır (Ruda, 2011, s. 151). Buradan hareketle Ruda, Hegelci devlet anlayışındaki sürekliliğin ve devletin organik bir birlik olarak varlığının herkesin eşitliğini askıya alan bir devlet anlayışına dayandığını belirtmektedir (Ruda, 2011, s. 157). Ruda, Hegel'in devlet anlayışında belirliliklerden yola çıktığını ve ayaktakımını bu belirlilikleri reddeden bir yapı olarak gördüğünü belirtmekte ve Hegel'in görevlerinden çözülmüş, haklarından mahrum kalmış bir yığın olarak adlandırdığı "ayaktakımı" ifadesinin pozitif her türlü belirlenimi reddeden negatif bir belirliliğin kısaltması olarak değerlendirmektedir (Ruda, 2011, s. 162). Bu noktada Ruda ayaktakımını devletten daha evrensel görmekte, ayaktakımının reddinin evrensele yönelik bir reddediş olacağını belirtmekte ve ayaktakımı probleminin devlete ait bir sorun olduğunu çünkü devletteki herkesin üstü kapalı yoksul ayaktakımı olduğunu vurgulamaktadır (Ruda, 2011, s. 163).

Ruda, Marx'ın modern burjuva toplumunda proletaryanın karşı karşıya kaldığı imkânsızlığı ayaktakımının imkânsızığıyla aynı görmekte ve ayaktakımının proletaryanın tüm karakteristik özelliklerini taşıdığını savunmaktadır. Ruda, Hegel'in ayaktakımının haksız bir tavrı olarak 
değerlendirdiği öfkeyi ise Marx’ın proletaryasının haklı komünist eyleminin temeli olarak görmektediriii. Ruda, Marx’ın öne sürdüğü bu komünist eylem ile ayaktakımının bedensiz bir organ olma durumunun aşılacağını, eşitlik ve adalete dayalı ortak bir bedene pek çok organın ekleneceğini belirtmekte ve düşünce ve siyasetin felsefeye olan baskınlığının ortadan kalkarak siyaset ve felsefesinin yeniden birleşeceğini öne sürmektediriv.

Dolayısıyla, Ruda da Avineri gibi ayaktakımı sorununa ilişkin tespitlerinde Hegel'i haklı bulmaktadır. Ancak Hegel'i ayaktakımını ve ayaktakımının öfkesini negatif bir anlayış olarak görmesini eleştirmekte, ayaktakımının içinde bulunduğu durumun kendi hatası veya iradesinin bir sonucu olmadığını belirtmektedir. Ona göre ayaktakımının Hegelci anlayışla hak edilmemiş hak iddiası eşitliğe ve adalete ilişkin bir hak, öfkesi ise eşitliğin ve adaletin haksızlığına ilişkin bir tutum olarak ele alınmalıdır.

\section{Yoksulluk Sorununa Reformist Refah Devleti Temelli Alternatif Çözüm Önerisi}

Yoksulluk sorununa ilişkin reformist bir refah devlet önerisi ile ön plana çıkan Raymond Plant sivil toplumu ihtiyaçlar döngüsü ile açıklamakta; bu döngü içerisinde insanların ihtiyaçların "kurbanı" veya "nesnesi" olmadığını, içgüdüsel ihtiyaçlar ve bu ihtiyaçları tatmin etmenin döngüsünden emek ile kurtulduklarını savunmaktadır (Plant, 1977a, s. 91). Bu noktada Plant Hegel'in doğal ve sosyal ihtiyaçlar ayrımının önemini vurgulamakta ve sivil toplumu ihtiyaçlar sistemi içinde bireylerin gerek karşılıklı bağımlılıklarını gerekse bireysel bağımsızlıklarını arttırdıkları bir modern toplum yapısı olarak değerlendirmektedir. Ona göre Hegel'in sivil topluma özgü bir sorun olarak gördüğü yoksulluk belirli bir toplumda entegre ve işlevsel bir konuma sahip kişinin bu faaliyetlerini sürdürebilmesi için gerekli olan yaşam ve tüketim standardının altına düşmesi ile ortaya çıkmaktadır (Plant, 1977b, s. 112). Plant bu çerçevede yoksulluğu fiziki bir mahrumiyet durumu olarak görmekte ve yoksulluğu, "yalnızca düşüşe geçen ve ayrışma yaşayan belirli toplumların bir özelliği değil, tam olarak düzgün işleyen -Hegel'in deyişiyle- engellenmemiş toplumların da bir özelliği" (Plant, 1982, s. 50) olarak açıklamaktadır. Plant, sorunun çözümünü ise refah artışında görmekte ve refah artışı için ise devlet müdahalesi önermektedir. Plant söz konusu çözümün "ekonominin yoksulluk içinde bulunan kişilere iş yaratabileceği ve bu yolla aşırı üretimin ortaya çıkaracağı sorunları alevlendirmeyebileceği" (Plant, 1982, s. 65) bir sistem içerisinde mümkün olacağını belirtmektedir. Plant, bu noktada aşırı üretim kaynaklı bir sorunun ortaya çıkışının ise kamu hizmetlerini geliştirerek ve alt yapıya destek sağlayacak işler yaratarak engellenebileceğini savunmaktadır. Böylelikle bir yandan 
yoksullara gelir elde etme şansı sunulacağını diğer yandan da tüketim mallarının aşırı üretiminin ve beraberinde getireceği sorunların engellenebileceğini belirtmektedir. Sivil toplumdaki yoksulların bir kısmının engelliler, hastalar ve kısıtlılar gibi kendi eylemleri dışında mahrumiyet yaşayan bireylerden oluştuğunu belirten Plant, bu bireylerin içinde bulundukları konumdan ve toplumun durumlarına çare üretmek için katlanacağı maliyetlerden sorumlu tutulmamaları gerektiğini vurgulamaktadır (Plant, 1982, s. 66).

Plant'e göre reformist bir yapıya kavuşturulacak olan böylesi bir refah devleti çalışma ilkesinin devamlılığını sağlaması açısından bir ödün olarak değerlendirilmelidir (Plant 1982: 67). Bu noktada Plant'in devlet müdahalesi görüşünün Hegel'in sivil toplum ve devlete ilişkin yapmış olduğu ayrımı ve buna bağıı olarak da sivil toplumun özerkliğini ortadan kaldıracağını söylemek mümkündür. Plant'in yoksulluğun çözümü için verilmesi gereken bir ödün olarak gördüğü "devlet müdahalesi" Hegel'in sivil toplum anlayışını dışarda bırakmaktadır. Çünkü Hegel'e göre bir devlet müdahalesi olacaksa bu müdahale sivil toplumun özerkliğini koruyacak şekilde ancak ekonomik eşitsizlik aşıı boyutlara ulaştığında dışsal bir müdahale ile sınırlı kalmalıdır.

\section{Yoksulluk Sorununa Korporasyon Temelli Alternatif Çözüm Önerileri}

Hegel yoksulluk sorununa ilişkin çözüm önerileri içerisinde bireysel çıkarların kitlesel güvenliğinin sağlanması ve bencil çıkarların evrensel amaçlara dönüştürülmesi açısından korporasyonlara önemli bir yer vermekte; korporasyonları adeta ikinci bir aile gibi nitelendirmektedir. Hegel'in korporasyonlara sivil toplum içerisinde vermiş olduğu bu konum yoksulluk sorununa ilişkin tartışmalarda korporasyonları tartışmanın merkezine yerleştirmektedir. Bu çerçevede korporasyon bazı çözüm önerilerinin odağında yer alırken bazılarında çözümün bir parçası olarak değerlendirilmektedir.

Korporasyonları yoksulluk sorununun çözümünde merkezi bir noktaya yerleştiren Joel Anderson, kamu otoritesinin ekonomiye müdahalesinin gerekliliğini kabul etmekle birlikte kamu otoritesini sorunun çözümü noktasında yetersiz görmektedir. Çünkü Anderson'a göre kamu otoritesinin bürokratik kurumları piyasaya dışsal olmaları nedeniyle çözüme yönelik dışsal müdahalelerde bulunurken, korporasyonların piyasaya, sektörlere, üretim ve tüketim davranışlarına ilişkin bilgi sahibi olmaları yapacakları müdahalenin kamu otoritesinin bürokratik kurumlarının müdahalesine göre daha içsel olmasına imkân sağlamaktadır (Anderson, 2001, s. 194-195). Bu bağlamda, korporasyonların üyelerine ve belirli sektörlerde yapılacak olan üretime yönelik sınırlandırmaları istihdam ve üretimde meydana gelmesi muhtemel sorunların önüne 
geçilmesini sağlamaktadır (Anderson, 2001, s. 199). Diğer taraftan, Anderson yoksulluk sorununun çözümünün korporasyonlar içerisinden yapılacak yardımlarla sağlanamayacağını, bu yardımların sorunu kısmen iyileştirmenin veya hafifletmenin ötesine gidemeyeceğini vurgulamaktadır (Anderson, 2001, s, 198). Anderson'a göre yoksullukla mücadele kapsamında üreticileri sınırlandırmak "makineleşme" ve "verimlilikteki değişmeler" söz konusu olduğunda üretimin orantısız artışı ve tüketimin sürekliliği açısından yetersiz kalmaktadır (Anderson, 2001, s. 200). Bunun yerine Anderson yoksulluk sorununun çözümünü tüketime yönelik bir farkındalıkta görmekte ve bu farkındalığı korporasyonlar içerisinde eğitim alarak yetişecek olan "sorumlu tüketicilerle" gerçekleşecek olan tüketim dönüşümü ile açıklamaktadır. Anderson sorumlu tüketiciyi “öğrenme sürecinden geçerek öz bilinç kazanan ve tüketimini toplumdaki genel kaynakları (vermögen) artırıcı şekilde yapan kişi" (Anderson, 2001, s. 203) olarak belirlemektedir. Bu belirleme göstermektedir ki Anderson'ın ortaya koymuş olduğu bu sorumlu tüketici ile gerçekleşecek olan farkındalıkla tüketim etik bir yapıya dönüşmektedir (Anderson, 2001, s. 205).

Richard Bellamy de Anderson'a benzer şekilde yoksulluk sorununun çözümünü korporasyonlar aracılığıyla sağlanacak olan bilinçlenme ve ortak refaha katkı ile açıklamaktadır. Bellamy yoksulluğun çözümü noktasında ön plana çıkarttığı farkındalığı zenginlerin tutum ve davranışlarındaki bilinçlenme ile açıklamaktadır. Bellamy’ye göre korporasyonlar "bireyin kendi çıkarının ötesine geçmesi ve ortak iyiliğin yararına olan bağıı̆ı̆ın geçerliliğini kavraması için bir araç sağlamaktadırlar" (Bellamy, 1987, s. 701). Bellamy bu çerçevede görüşünü "yoksulluk sorununun çözümü yoksulların entegrasyonundan değil, zenginlerin davranışlarını ve tutumlarını değiştirmelerinden gelmektedir" (Bellamy, 1987, s. 701) şeklinde ifade etmektedir.

Hegel'in yoksulluk sorununun çözümüne ilişkin önerilerine yönelik tartışmada ön plana çıkan bir diğer önemli isim olan Ferro yoksulluk sorununa doğrudan Hegel tarafından bir çözüm ortaya konulmadığını, ancak çözüme ilişkin Hegel'in analizlerinde önemli temeller bulunduğunu vurgulamaktadır. Ferro'ya göre yoksulluk, "ekonomik yollarla çözülmesi gereken basit bir ekonomik sorun" olmanın ötesinde sosyal yabancılaşma kaynağı olarak değerlendirilmelidir (Ferro, 2020, s. 60). Nitekim Hegel'in de altını çizdiği üzere yoksulluk yalnızca bir yoksunluk durumu olarak şekillenmemekte, aynı zamanda toplumdan dışlanma hissini açığa çıkartan bir sosyal yoksunluğu da ifade etmektedir. Bu nedenle Ferro'ya göre yoksulluğun çözümü "yoksulların toplumun küresel ağında tanınarak yeniden bütünleştirilmesini amaçlayan daha derin bir sosyal dönüşüm" (Ferro, 2020, s. 61) ile mümkün görünmektedir. 
Yoksulluk sorununun ekonomik ve etik boyutlarına da dikkat çeken Ferro, sorunu sosyal tanınma eksikliği ile ilişkilendirmekte ve bunu yoksul ile ayaktakımı arasındaki ayrım ile ortaya koymaktadır. Ferro yoksulları "mesleki görevlerini inmal edemedikleri, statükoya isyan etmenin yasal sonuçlarından korktukları ya da standartlarını iyileştirme olasılığına inandıkları için yasalara saygılı vatandaşlar olarak" (Ferro, 2020, s. 70) değerlendirirken, ayaktakımı için "mevcut sosyal düzen altında böylesi bir iyileştirmenin mümkün görülmediğini" (Ferro, 2020, s. 70) ifade etmektedir. Anderson'ın kamu otoritesinin bürokratik kurumları ile yoksulluğun çözümüne ilişkin müdahalelerini dışsal müdahaleler olarak değerlendirerek yetersiz bulması ve korporasyonları sorunu çözecek içsel bir kurum olarak görmesine benzer şekilde, Ferro da kamu otoritesinin sorunun yalnızca ekonomik boyutuna odaklandığını, korporasyonlarda ise sorunun hem ekonomik hem etik boyutlarına odaklanıldığını savunmaktadır (Ferro, 2020, s. 75). Ferro, korporasyonları, Hegel'de olduğu gibi, ihtiyaç duyulan sosyal dönüşümün gerçekleşebileceği "ikincil bir aile" yapısı olarak ele almaktadır. Korporasyonlara yönelik eleştirilerin merkezinde, yalnızca üyelerine ve çalışanlara ilişkin koruyucu bir rolü olduğu bu rolün işsizleri ve ayaktakımını içermediği düşüncesinin bulunduğunu belirten Ferro, korporasyonların işgücü piyasasını genişletme ve iyileştirme amacının bu eleştirilerde göz ardı edildiğini belirtmektedir (Ferro, 2020, s. 75). Ona göre, korporasyonların bu rolü sayesinde "daha az" insan işsizlik, tatminsizlik ve sosyal dışlanma riski yaşayacak; korporasyonlar içerisinde gerçekleşecek olan sosyal tanınma sivil toplumun bireysel çıkarcı yapısından devlete geçişin ilk adımını oluşturacaktır. Yoksulluğa ilişkin Ferro da tıpkı Anderson ve Bellamy’nin analizlerinde olduğu gibi korporasyonlar içerisinde veya vasıtasıyla gerçekleşecek olan bilinçlenme ve farkındalığa benzer bir perspektif değişimini çözümün temeline yerleştirmektedir. Bu noktada Ferro korporasyonların Hegel tarafından belirlenen niteliğinin gözden kaçırılmaması gerektiğini belirtmekte ve korporasyonların kapalı lonca sistemlerinden farklı olarak kamu denetimine ve sosyal katılıma açık oldukları durumda sosyal tanınmaya katkı sağlayabileceklerini vurgulamaktadır (Ferro, 2020, s. 76).

Dolayısıyla Ferro yoksulluk sorununun çözümünün korporasyonlar ile gerçekleşeceğini belirtmekte ve çözümü korporasyonlarda meydana gelecek olan sosyal tanınmanın ortaya çıkaracağı bir perspektif değişiminde görmektedir. Korporasyonların bu rolünün yanı sıra Ferro korporasyonların beraberinde getirebileceği belli başlı sorunlara da dikkat çekmektedir. Buna göre korporasyonlar "devlet içindeki belirli grupları temsil ettiklerinden diğer korporasyonlarla ve siyasi temsilcilerle etkileşimleri yoluyla sivil toplumun atomistik mantığını daha üst seviyede -bireysel atomlardan ziyade kolektif atomlardan oluşacak şekilde- yeniden oluşturabilirler" 
(Ferro, 2020, s. 77). Bu durum korporasyonlar yoluyla sivil toplumun bireysel çıkarlarının kolektif çıkarlara dönüşmesi tehlikesini ortaya çıkarmaktadırvi. Korporasyonların Hegel'in yaşadığı dönemde bile çağdışı olduğunu düşünen Ferro'ya göre yoksulluk sorununun çözümünde korporasyonların içeriğinin günümüz şartlarına uygun şekilde belirlenmesi gerekmektedir. Bu çerçevede Ferro korporasyonlara yönelik "ulusal veya uluslararası düzeyde sivil toplum örgütlerini, devlet dışı organizasyonları ve siyasi partileri" içerecek bir uyarlamayı örnek olarak vererek böylesi yapılarla kolektif güçlerin daha etkin işlev göreceğini belirtmektedir (Ferro, 2020, s. 77).

Polis ve korporasyon seçeneklerini yoksulluk sorununun çözümünde doğrudan etkili görmeyen ve çözümün özgürlük gelişiminin "en üst noktası olan devlet" aşamasında gerçekleştiğini öne süren Jeff Jackson ise yoksulluğun çözümünü özgürlüğün gelişimindeki diyalektik harekette, olumsuzlamanın olumsuzlanmasıyla, yani kapsayarak aşma ile açıklamaktadır (Jackson, 2014, s. 336). Bu çerçevede Jackson, devletin sadece "var olmak" değil, aynı zamanda "gerçek" hale gelmesine ilişkin bir analizden hareket etmektedir. Devletin bu durumunu "özgürlüğü destekleyen nitelikleri koruyarak özgürlüğü engelleyen nitelikleri ortadan kaldırması" olarak (Jackson, 2014, s. 332) açıklayan Jackson'a göre, yoksulluk sivil toplumun bir çelişkisi olduğundan devlet tam da Hegel'in diyalektik sistemine uygun olarak böylesi çelişkili nitelikleri kapsayarak aşarak yalnızca var olmamakta, aynı zamanda gerçek olmaktadır. Bu nedenle Jackson yoksulluğun bir defada değil aşamalı olarak ortadan kaldırılacağını savunmaktadır. Ona göre polis ve korporasyonlar aracılığıyla ulaşılacak bir çözüme güvenmek sivil toplumun kendi başına yeterliliği olduğu düşüncesine dayanmaktadır (Jackson, 2014, s. 333). Ancak Jackson'a göre polis ve korporasyonlar sivil toplumun kusurlarını hafifletebilmekte, ancak diyalektik sistem gereği bu çelişkileri kapsayarak aşamamaktadır. Buna bağlı olarak Jackson devlet kontrolünü öngörmekte, ancak sivil toplumun içsel doğasını bozmayacak şekilde korporasyonların bağımsızlığının tamamıyla ellerinden alınmaması gerektiğini de vurgulamaktadırvii (Jackson, 2014, s. 348). Böylece sivil toplumun özgürlüğü geliştirici özsel yönleri korunurken, yoksulluk gibi çelişkili yönleri aşılmaktadır. Bu noktada Jackson, Avineri'nin yoksulluğu sona erdirmek için gerçekleşecek olan devlet müdahalesinin diyalektik olmayacağına ve devletin sivil toplumu ortadan kaldırarak "dolayımsız" bir bütün olacağına ilişkin görüşlerini eleştirmekte; devletin daha üst bir birliği teşvik etmesinin sivil toplumu ortadan kaldırmayacağını, aksine yükselteceğini belirtmektedir. Jackson bu durumu “özgürlüğün gerçekleşmesi sivil toplum tarafından daha da güçlendirilir. Çünkü sivil toplum 
içerisinde yer alan özgürlüğün gelişimi önündeki engeller aşamalı olarak aşılır" (Jackson, 2014, s. 343) şeklinde dile getirmektedir.

Bu çerçevede Jackson devletin sivil toplumu kapsayarak aşmasında günümüzde de aktif bir şekilde uygulanan "evrensel temel gelir" uygulamasını ön plana çıkartmaktadır. Jackson evrensel temel gelir uygulamasının Namibya, Amerika Birleşik Devletleri ve Kanada'da istihdam üzerindeki olumlu etkilerini referans göstererek sivil toplumdaki bireylere eşit olarak davranılması ve temel ihtiyaçlarının karşılanması için belirli bir miktar paranın düzenli olarak ödenmesinin öznel yardımların onur kırıcı etkisini ortadan kaldıracağını savunmaktadır (Jackson, 2014, s. 350). Aynı zamanda Jackson bu uygulamanın sivil toplumun kendine yeterlilik prensibine de uyduğunu belirtmekte ve sorunu tamamen çözmese de aşamalı olarak yoksulluk üzerinde olumlu bir etki yaratacağını belirtmektedir.

Hegel'in yoksulluk sorununu bilinçli olarak çözümsüz bıraktığını savunan Matt Whitt yoksulluğun Hegel tarafından toplumun kalkınmasına katkı sağlayan bir etmen ve özgürlüğün gerçekleşmesinde diyalektik bir koşul olarak görüldüğünü belirtmektedir (Whitt, 2013, s. 260). Whitt yoksulluğun törel devletin gelişimine katkı sağlayacağını ifade ederek yoksulluğu egemenliğin içsel boyutu ile ilişkilendirmektedir. Devletin içsel egemenliği elde etmek için içsel bir ötekini olumsuzlaması gerektiğini öne süren Whitt'e göre bu içsel öteki “yoksullaşmış ayaktakımıdır" (Whitt, 2013, s. 271). Ayaktakımı oluşumunu etik topluluğun uyumu için içsel bir tehdit olarak gören Whitt, bu oluşumun devlet için bir içsel öteki rolü oynadığını belirtmektedir. Hegel'in sistemi içinde yoksulluğa ilişkin bir çözüm üretilememesinin nedeni sistemin tutarlılığı açısından ayaktakımının devletin egemenliği için içsel bir öteki olarak varlığını sürdürmesi gerekliliğidir.

Thom Brooks ise yoksulluk sorununu ayaktakımının öz kimlik duygusu üzerinden ele almakta ve sorunun sosyal ve politik bir yabancılaşma nedeniyle ortaya çıktığını öne sürmektedir (Brooks, 2015, s. 7). Avineri ve Plant'i yoksulluk sorununu yaşam standartlarındaki gerilemeye indirgemeleri nedeniyle eleştiren Brooks, sorunun kökenini kişinin hak, dürüstlük, onur gibi duyguları yitirmesine bağlı olarak sosyal ve politik hayattan kopmasında görmektedir. Diğer taraftan yoksulluğu ekonomik yabancılaşmaya ek olarak sosyal, ahlaki ve siyasi yabancılaşma olarak tanımlayan Pimenta (Pimenta, 2020, § 50) yoksulluk sorununun Hegel tarafından diyalektik olarak çözülememiş bir aporia olarak bırakıldığını vurgulamaktadır (Pimenta, 2020, § 53). 
Korporasyonlar kurumsal yapıları ve işlevleri üzerinden pek çok yazar tarafından eleştirilmektedir. Bu durum korporasyonlarda reform yapılması ihtiyacını gündeme getirmektedir. Yoksulluk sorununun çözümünü korporasyonlarda gören Ferro, söz konusu kurumların yoksulluk sorununu işgücü piyasasındaki genişletme ve iyileştirme fonksiyonları vasıtasıyla çözebileceğini, ancak bu çözümün korporasyonları kamu denetimine ve sosyal katılıma açık hale getirecek bir modernizasyon sonrasında mümkün olabileceğini vurgulamaktadır (Ferro, 2020, s. 61). Korporasyonları yoksulları sisteme yeterince dahil edememesi üzerinden eleştiren lan Fraser ise çözümün yoksulların "kendi özel ve evrensel yönlerini birbirleriyle uyumlu hale getirmeleri" (Fraser, 1996, s. 2060) ile mümkün olacağını savunmaktadır. Buna göre Fraser'ın önerisi yoksulların örgütlenmesini ima etmekte ve Marksizm odaklı önerilerle benzerlik göstermektedir. Yoksulluk sorununu bir aporia olarak gören Pimenta da korporasyonların Hegel'in sisteminde içsel bir çelişki yarattığını öne sürmekte ve bu görüşünü Hegel'in yaşadığı dönem içerisinde bu kurumların yasaklanması ile desteklemektedir (Pimenta, 2020, § 53). Jackson, korporasyonların yoksulluk sorununun çözümünde önemli bir rolü olduğunu kabul etmekte birlikte, aralarında yoksulluğun da bulunduğu sivil toplumun çelişkilerini yalnızca hafifletebildiklerini, ancak diyalektik sistem gereği kapsayarak aşamadıklarını belirtmektedir (Jackson, 2014, s. 348). Teichgraeber de yoksulluk sorununun, korporasyonlar modernize edilse dahi korporasyonlar vasıtasıyla çözülemeyeceğini ve sorunun çözümünde devletin mutlaka aktif olarak görev alması gerektiğini vurgulamaktadır (Teichgraeber, 1977, s. 61).

Korporasyon temelli çözüm önerileri Hegel'in korporasyonları devlet aşamasına geçişte önemli bir sivil toplum kurumu olarak benimsemesine odaklanmaktadır. Frankfurt Okulunun önemli düşünürlerinden Axel Honneth Hegel'e ilişkin yaptığı analizlerde korporasyonların bir sivil toplum kurumu olarak belirlemesine tanınma görüşü çerçevesinde karşı çıkmaktadır. Özgürlüğün ve kendini gerçekleştirmenin öznelerarası tanınma ile gerçekleşeceğini savunan Honneth (Honneth, 2010, s. 214), aile, sivil toplum ve devlet aşamaları arasındaki hiyerarşik ilişkiyi ele almakta ve bu hiyerarşiyi öznenin her bir aşamada daha yüksek bir bireyselleşmesinin ortaya çıkması ile açıklamaktadır (Honneth, 2010, s. 59). Honneth'e göre devlette de sivil toplum alanından daha yüksek bir bireyselleşme ortaya çıkmakta ve bu durum öznenin devlet alanında gerçekleştirebildiği evrensel aktiviteden kaynaklanmaktadır (Honneth, 2010, s. 60). Bu noktada Honneth, devlet alanındaki daha yüksek olan bireyselleşmeyi bireylerin becerilerini ve 
yeteneklerini ortak çıkar doğrultusunda sınırlandırmayı öğrendikleri ve bu doğrultuda kamusal bir hayat sürmelerinin onayını aldıkları korporasyonlarla ilişkilendirmektedir.

Honneth öznenin devlet alanında doğal ihtiyaçları ve kişisel ihtiyaçları ile değil becerileri ile toplumun bir üyesi haline geleceğini savunmaktadır (Honneth, 2010, s. 61). Honneth ayrıca, Hegel'in ortak amaçları paylaşan korporasyon üyelerinin aynı zamanda sivil toplumun özgürleşmiş ve bağımsız bir üyesi olmasına ve korporasyonların kapitalist bir piyasaya ahlaki bir disiplini empoze etmeye çalışmasına yönelik beklentisini de fazla iyi niyetli bulmaktadır (Honneth, 2010, s. 75). Bu çerçevede Honneth, korporasyonların Hegel tarafından sivil toplum alanına yerleştirilmesini eleştirmektedir. Ona göre korporasyonların sivil toplum alanına yerleştirilmesi biri piyasa tarafından aracılık edinen işlemlerle, diğeri ise değer odaklı etkileşimlerle ilişkili olan tanınmanın farklı iki biçiminin aynı alana yerleştirmesi anlamına gelmektedir (Honneth, 2010, s. 77). Honneth bu doğrultuda kolektif bir yapılanmaya sahip korporasyonların bireysel özerklik alanı olan sivil toplumda yer alamayacağını ve bu yapıların devlet alanında yer alması gerektiğini savunmaktadır. Böylece, Honneth korporasyonların "Ionca benzeri bir kurum olarak değil öznelere kendi bireysel aktivitelerinde bir evrensellik hissi veren, kamusal olarak aracılık edilen ve demokratik bir işbirliğinin göstergesi olarak kendini bulduğu bir kamusal özgürlük alanında" yer alabileceğini belirtmektedir (Honneth, 2010, s. 77).

Diğer taraftan, Honneth, yoksulluk sorununu korporasyonlar üzerinden incelememekte; sorunu yeniden dağılım ve tanınma arasındaki ilişki üzerinden ele almaktadır (Schweiger, 2015, s. 144). Nancy Fraser ise yoksullukla mücadelede yeniden dağılım politikalarını ve tanınmayı birbirleriyle ilişkileri çerçevesinde ele almaktadır. Ancak Fraser, söz konusu ilişkiyi düalist bir yaklaşımla gelirin yeniden dağıımının tanınma üzerindeki olumsuz etkilerinin önlenmesi amacıyla "olumlama" ve "dönüştürme" yöntemleri üzerinden incelemektedir. Fraser’a göre olumlama yöntemi, sosyal düzenlemelerin adaletsiz sonuçlarını onları oluşturan temel sosyal yapıları bozmadan düzeltmeyi amaçlarken; dönüştürme yöntemi temelde yatan üretken çerçeveyi yeniden yapılandırarak adil olmayan sonuçları düzeltmeyi amaçlamaktadır. Fraser, olumlama yöntemine liberal refah devletindeki mevcut ekonomik yapıyı değiştirmeksizin uygulanan gelir transferini örnek olarak vermektedir. Ona göre bu düzenleme ile dezavantajlı grupların tüketimden aldığı payın arttırılması amaçlanmaktadır. Dönüştürücü yönteme ise adaletsiz dağılımı adaletsizliği yaratan çerçeveyi dönüştürerek kalıcı olarak ortadan kaldıracağını düşündüğü sosyalizm örneğini vermektedir (Fraser ve Honneth, 2003, s.74). 
Fraser, yeniden dağılımda olumlama yönteminin tanınma üzerinde yaratacağı olumsuz etkilerin dönüştürme yönteminde ortaya çıkmayacağını savunmaktadır. Ona göre yeniden dağılıma ilişkin olumlama yöntemini esas alan yaklaşımlar grup kimliğini tek bir eksene oturtmakta, bireylerin kendilerine dönük anlayışlarını basitleştirmekte, onları tek bir grup tipine uymaya zorladığından insanlar arasında ayrılıkçılığa (separatism) yol açmaktadır (Fraser ve Honneth, 2003, s. 76). Olumlama yöntemini kullanan yaklaşımların diğer eksik yönünün ise yoksulluk sorununu çözmek yerine, yoksul kişilerin aldıkları desteklere muhtaç hale getirilmeleri ve halihazırda sahip oldukları yoksunluğa yardımlarla maruz kaldıkları damgalanmanın yarattı̆̆ı saygıdan yoksunluğun da eklenmesi olduğunu belirtmektedir. Dönüştürücü yöntemi esas alan yaklaşımlar ise dayanışmayı teşvik etmekte ve yoksulluğu azaltmanın yanı sıra toplumun ekonomik yapısından kaynaklanan yanlış tanınma biçimlerini de düzeltmeye yardımcı olmaktadır. Bu çerçevede dönüştürücü yaklaşımlar pastayı genişletmeye ve emeğin genel koşullarını yeniden yapılandırmaya odaklanarak eşitsizlikleri yardımları alan kişilerin maruz kaldığı damgalanma olmaksızın azaltmayı amaçlamaktadır (Fraser ve Honneth, 2003, s. 77). Bu çerçevede, yoksulluk sorunu Honneth ve Fraser'ın da içinde bulunduğu düşünürler arasında tanınma ve adalete ilişkin güncel bir tartışmaya da konu olmuştur.

\section{Yoksulluk Sorununa Hegel’in Sistemine İçkin Bir Çözüm Önerisi}

Hegel, ölümünden bir asır sonra ortaya çıkacak ve milyonlarca kişiyi yoksulluğa itecek büyük bir krizi adeta öngörerek, her ne kadar yetersiz düzeyde kalsa da, bazı çözüm önerileri ortaya koymuştur. Toplumun genelini ilgilendiren ve ayaktakımına dönüş gibi önemli bir risk içeren yoksulluk sorununun kendiliğinden ortadan kalkmasını beklemektense, topluma ait olan kamu kaynaklarını kullanan devletin de aktif rol aldığı daha geniş çaplı bir çözüm arayışına girmek daha rasyonel bir çözüm olarak ön plana çıkmaktadır. Nitekim, 1929 yılındaki Büyük Bunalım ile gerek Keynesyen politikaların popülaritesi artmış gerekse iktisat biliminin bir alt dalı olan kalkınma iktisadının temelleri atılmıştır. Hegel, liberal ekonominin temel prensiplerini benimsemekle birlikte, serbest piyasanın yıkıcı etkilerinin de farkındadır (Ferro, 2020, s. 73). Dolayısıyla, düşünce sisteminde oluşturduğu kamu otoritesi ve korporasyonların bu yıkıcı etkileri kontrol altında tutmak amacıyla kullanılabilecek bir nevi uzlaştırma kurumları olduğu öne sürülebilir. Bu noktadan hareketle, Hegel'in ekonomiye ilişkin görüşleri tamamen liberal bir çerçevede değerlendirilemeyeceği gibi, tamamen Marksist bir çerçevede de değerlendirilmemelidir. 
Bu çalışmanın amacı Hegel'in yoksulluk ve ayaktakımı sorununa Hegel'in düşünce sistemi içerisinde ve dönemin şartları dikkate alınarak bir çözüm önerisi getirmektir. Marx’ın yoksullaşmayı servet artışının beraberinde getirdiği emeğe yabancılaşma ile açıklaması ve Hegel'in yoksulluğu sivil toplumun iyi işleyen mekanizmasının bir ürünü olarak görmesi arasında sıkı bir benzerlik bulunmaktadır. Aynı zamanda Marx'ın yabancılaşma sorununu insanın emeğinin ürününe, emek sürecine, türsel varlığına ve insana yabancılaşması olarak dört farklı boyutta değerlendirmesi yoksulluk sorununu yalnızca ekonomik bir sorun olarak görmediğini de göstermektedir. Ancak Marx’ın yabancılaşma sorunun çözümünü yabancılaşmış, mülksüz, yoksul ve sefalet içerisinde bırakılmış proletarya sınıfının "proleter hareketi" ile gerçekleşecek olan sınıflı toplum yapısının ortadan kaldırılmasında görmesi Hegel'in devlet aşamasına geçişte zorunlu bir aşama olarak gördüğü sivil toplumun ortadan kaldırılması sonucunu beraberinde getirmektedir. Bu çerçevede, sivil toplum aşamasının konumunun Hegel'in sistemindeki diyalektik bütünsellikte korunması amacıyla Marx’ın ekonomik anlayışı ve yönetim biçimini kökten değiştirmeyi temel alan önerileri çözüm kümesinin dışında bırakılmıştır. Buna ek olarak, özel mülkiyetin ortadan kaldırılmasını gerektiren modeller ve Smith'in görünmez el metaforu çerçevesinde tamamen serbest piyasa temelli bir ekonomik yaklaşım öngören liberal çözümler de -yine Hegel'in sisteminin dışına çıkmamak adına- kapsam dışında tutulmuşturviii.

Hegel'in esas olarak yoksulluğun ayaktakımına dönüşümü ile radikal bir sorun haline geldiğini belirtmesi, yoksulluğa ilişkin bu bölümde önerilecek çözümlerin de bu durumu dikkate alacak biçimde tasarlanmasını gerektirmektedir. Diğer taraftan, Hegel'in analizinde ayaktakımı oluşumu ve bu oluşumun beraberinde getirdiği öfke, çözülme, evrenselden kopuş gibi olumsuzluklar yoksulluk oluşumu sonrası ortaya çıktığından, bahsedilen olumsuzluklar tamamıyla ekonomik olmasa da çözüm önerilerinin ekonomi temelli olmasını kaçınılmaz kılmaktadır. Bu noktada, sivil toplumun rasyonelliği sonucu oluşan bir irrasyonelliğin devlet, piyasa oyuncuları ve korporasyonların etkin iş birliği ile sivil toplum ve devlet aşamaları arasında çözülmesi gerekmektedir. Buradaki beklenti yoksulluk ortadan kalktığında ayaktakımı zihniyetinin de ortadan kalkacağıdır.

Hegel, yoksulluk sorununa öznel yardımlar, yoksullara doğrudan iş imkânı sağlanması ve kolonizasyon gibi önerilerle kamu otoritesi ve korporasyonlar üzerinden bir çözüm kapısı aralamış, ancak bu önerilerin kökten bir çözüme yol açmadığını belirtmiştir. Hegel sivil toplumun üyelerinin özel yetenekleri vasıtasıyla korporasyonlara üye olabileceğini ve korporasyon üyeleri arasındaki koruyucu-kollayıcı yapı sayesinde geçimlerini sağlamayı güvence 
altına alacaklarını belirtmektedir. Bu sayede yoksulların aldığı yardımın yoksulları düşürdüğü haksız konumu ve buna bağlı olarak ortaya çıkan aşağılanmayı ortadan kaldıracağını düşünen Hegel, diğer çözüm önerilerine kıyasla korporasyonların yoksulluğu azaltmada başarıya biraz daha yakın olduğunu ima etmektedir. Diğer taraftan, korporasyonlar yoksulluk sorununun çözümü için önemli bir potansiyel barındırsa da Hegel'in kurguladığı haliyle başarıya ulaşmaya uzaktır. Kalıcı ve kesin bir çözüm için Hegel'in sisteminde yer alan korporasyonların gerek amaç gerekse faaliyet şekli itibarıyla güncellenmesi ve yoksulluk sorunun çözümündeki aktif rolünün buna uygun olarak belirlenmesi gerekmektedir. Buna göre, korporasyonların Hegel dönemindeki lonca tipi bir yapılanmadan ziyade, günümüzdeki meslek odalarının, kooperatiflerin ve sendikaların bazı işlevlerini, görevlerini ve yetkilerini bünyesinde barındıran karma yapılara sahip olacak biçimde dönüştürülmesi büyük önem arz etmektedir. Bu yapı yoksulluğun çözümünde korporasyonların rolünün bundan daha fazlası olması gerektiğini düşünen Anderson'ın (Anderson, 2001, s. 199) ve yoksulluk sorununun çözümünün esas olarak korporasyonlarda gerçekleşebileceğini düşünen Ferro ve Bellamy'nin görüşlerine de uygunluk göstermektedir. Böylece korporasyonlar sivil toplum ve devlet arasında gerçek bir köprü görevi görecek, yoksulluk ve ayaktakımı sorununun çözümünde kilit nokta halini alacaktır.

Hegel'in, yoksulluk ve ayaktakımı sorununa ilişkin çözüm önerilerinden birisi olan öznel yardımlar günümüzdeki sosyal yardımlara benzemekte, fakat herhangi bir devlet müdahalesi olmaksızın bireylerin vicdani yükümlülük duyarak yaptıkları bireysel yardımları kapsamaktadır. Bu tarz yardımlar Hegel'in belirttiği üzere, yoksulluk sorununa çözüm olamadığı gibi, kişiyi rencide etmekte ve yardım alanlarda aşağılanma duygusu yaratmaktadır. Diğer taraftan, günümüzdeki sosyal yardım sistemleri incelendiğinde, bu tarz yardım ve desteklerin yoksullukla mücadelede etkin olarak kullanıldığı dikkat çekmektedir. Burada önemli olan husus, yardımların aşağılanma hissi yaratmaması ve yardım alan bireyleri çalışma hayatının dışına itmemesidir. Yardım alan bireyde aşağılanma hissi yaratmamak için öznel yardımlar evrensel gelir desteği biçimine dönüştürülerek korporasyonlar vasıtasıyla herkese eşit şartlarda ve en düşük geçim seviyesini sağlayacak miktarda uygulanabilecektir. Ayrıca, bireyin çalışma isteğinin korunması ve işgücü piyasasında kalmayı sürdürmesi için de yardım alma koşulu iş aramayı sürdürme şartına bağlanabilecektir. Zira, Hegel sivil toplum içindeki bireyin özgürlüğünü ve tanınmasını çalışma şartına bağladığından, yardım alan kişinin bu yardıma güvenerek işgücü piyasasından çekilmesi, yoksulluk sorununa niceliksel olarak çözüm olsa da Hegelci çerçevede niteliksel olarak çözüm olamayacaktır ${ }^{i x}$. Böylece, bireyler iş arama süreçlerinde en temel ihtiyaçlarını 
karşılayarak öfke ve çözülme hissinden uzaklaşacak ve topluma duydukları aidiyet hissini koruyacak, iş bulduklarında ise geçimlerini sağlayacakları için yoksulluğa düşmekten kurtulacaklardır. Ayrıca, çözüm önerisinde evrensel gelir desteği uygulamasının çalışma şartına bağlanmasıyla Fraser'ın olumlama yönteminde ortaya çıkacağını belirttiği damgalanma, muhtaçlık ve saygıdan yoksunluk gibi olumsuzluklar söz konusu olmayacaktır. Bu sayede yoksulluk sorununun niceliksel boyutuna ek olarak niteliksel boyutu da çözülmüş olacaktır. Bu noktada, devlet günümüzde pek çok ülkede uygulanan asgari ücret benzeri bir sistemi zorunlu kılarak bireylerin iş buldukları durumda yoksulluktan, dolayısıyla da ayaktakımı olma riskinden, uzak kalmalarını sağlayabilecektir. Asgari ücret gibi bir düzenlemenin getirilme nedeni çalışanların temel ihtiyaçlarını karşılayamayacak seviyede bir ücret karşıı̆̆ında çalışmaları durumunda da yoksullar arasına dahil olabilecek olmalarıdır. Dolayısıyla, modele yapılacak bu eklemenin tek amacı çalışan ve ücret elde eden kişilerin yoksullaşmalarını engellemektir.

Diğer taraftan, Hegel'in öne sürdüğü öznel yardımların yukarıda bahsedilen haliyle uygulanması yoksulların ayaktakımına dönüşümünü engellemek için kısa vadede uygulanabilecek geçici bir çözümdür. Buradaki amaç kişinin ayaktakımına dönüşmeden önce yoksulluktan kurtarılmasıdır. Nitekim, ayaktakımına dahil olan bir kişinin sisteme olan öfkesinin giderilmesinin ve evrensele tekrar bağlanmasının sağlanması çok kolay olmayacaktır. Bu kişilerin kalıcı olarak yoksulluktan uzak tutulmaları için piyasanın ihtiyaç duyduğu niteliklere ve eğitim seviyesine sahip olmaları gerekmektedir. Nitekim, bu kişilere sağlanacak işler doğrudan devlet tarafından değil, korporasyon üyeleri tarafından sağlanmaktadır. Bu noktada devletin görevi iş arayan kişilerin nitelikli çalışanlar olabilmelerini desteklemek için becerilerini geliştirmelerini ve keşfetmelerini sağlamak amacıyla yüksek kaliteli ve herkesin eşit şansa sahip olduğu bir eğitim almalarını sağlamaktır. Korporasyonların da devletin verdiği eğitimi günümüzde de uygulanan çıraklık, staj, işbaşı eğitim gibi uygulamalı eğitimlerle desteklemesi gerekmektedir. Böylece, bireyler hem piyasanın ihtiyaç duyduğu niteliklere sahip olarak daha kolay iş bulabilecek hem de daha nitelikli çalışanlar olmaları nedeniyle üretime daha fazla katkı sağlayabileceklerdir. Ayrıca, bireylerin işgücü piyasasındaki değişimlere paralel olarak sahip olmaları gerekecek yeni rollere uyum sağlayabilmeleri için devlet ve korporasyonlar tarafından verilecek eğitimlerin yaşam boyu eğitim uygulamaları ile desteklenmesi gerekmektedir.

Eğitim ile oluşacak olan yeni bireysel özgürlük bilincinin korporasyonlar vasıtasıyla ekonomik süreç ve ilişkilerde yaşanacak değişikliklere dayanıklı hale getirilmesi büyük önem arz etmektedir. Yoksullukla mücadelenin uzun vadeli çözüm ayağı olan eğitim reformu sürecinde 
ekonomik koşullarda ve iş yapış süreçlerinde önemli değişiklikler yaşanabileceğinden, sistemin başarıyla sürdürülebilmesi için korporasyonların sektörel eğilimleri tahmin ederek üretimi gelecekte öne çıkacak sektörlere yönlendirmesi ve devlete işgücünün durgun sektörlerden yüksek büyüme gösterecek sektörlere geçişi ile bilgi sağlaması gerekecektir. Bunun gerçekleşmesi için ise korporasyonların piyasa hakkında en üst düzey bilgiye sahip olması ve gerek ulusal düzeyde gerekse küresel düzeyde güncel gelişmeleri takip etmesi gerekmektedir.

Hegel'in sistemi çerçevesinde yoksulluk sorununa çözüm aranan bu çalışmada önerilen modelde Plant'in öngördüğü derecede ekonomide bir devlet müdahalesi veya tam anlamıyla bir refah devleti önerilmemektedir. Bunun yerine bireyin asgari ücret, evrensel gelir desteği gibi günümüzde de yoksullukla mücadele programlarında uygulanmakta olan bazı iktisadi unsurlarla kısmen koruma altına alındığı ve esas olarak işgücü piyasasında tutunarak ayaktakımına dönüşümünün engellenmesinin amaçlandığı olası bir çözüm önerisi getirilmektedirx. Zira günümüzde de gelir dağılımı eşitsizliklerinin ve yoksulluk oranlarının en düşük düzeyde olduğu ülkeler eğitim seviyesi en yüksek ülkelerdir. Diğer taraftan, iş arayan bireylere verilecek şartlı evrensel gelir desteği kısmen de olsa refah devletinin işlevlerine atıfta bulunmakta olup, ayaktakımına dönüşen yoksul bireylerin yaşamları için doğrudan devlet desteğine ihtiyaç duyacağını belirten, ancak Hegel'in devletinin bir refah devleti olmaktan uzak olduğunu savunarak (Teichgraeber, 1977, s. 61) korporasyonları bir çözüm olarak görmeyen Teichgraeber'in eleştirilerine cevap niteliğindedir.

Bu çalışmada yoksulluk sorununa Hegel'in düşünce sistemi içerisinde korporasyon temelli ve sisteme içkin olası bir çözüm önerisi getirilmesi amaçlanmıştır. Bu çerçevede, çözümün sivil toplum aşamasında ve devletin kontrolü altında aşamalı bir biçimde gerçekleşmesi öngörülmüş; doğrudan devlet müdahalesi veya tam refah devleti oluşumu içerilmemiştir. Bireyler asgari ücret, evrensel gelir desteği gibi iktisadi unsurlarla kısmen koruma altına alınmış, esasen işgücü piyasasında tutunmaları ve kendilerini değerli hissetmeleri sağlanarak ayaktakımına dönüşmelerinin engellenmesi amaçlanmıştır. Bunun için Hegel'in sistemindeki diyalektik süreç çerçevesinde devlet aşamasına geçişteki kapsanarak aşılmada korporasyonların aracı rolü göz önünde bulundurulmuştur. Bu bağlamda, korporasyonların rolü yoksullara kendilerine değer verildiğini hissettirecek yukarıda belirtilmiş olan politikalarla güncellenmiştir. Çözüm önerisinin merkezinde korporasyon ve eğitim reformları bulunurken; çözüm, farklı yaklaşımlardan unsurlar barındıran melez bir model olması ile literatürdeki korporasyon temelli çözüm önerilerinden farklılaşmaktadır. 
Diğer taraftan, yoksulluk sorununa ilişkin olarak bu çalışmada ortaya konulan çözüm önerisi yoksulluk sorunu yaşayan tüm ülkelerde uygulanabilecek mutlak, iktisadi bir reçete olarak değerlendirilmemelidir. Bunun yerine, literatürde Hegel'in yoksulluk sorununu çözümsüz bıraktığını öne süren çalışmalardan hareketle; Hegel'in yoksulluğun ayaktakımına dönüşümü ile radikal bir sorun haline geldiğini belirtmesinin ve evrenselden kopuk, kendi emeği ile yaşamak onurunu, hukuka olan saygısını ve kendine olan güvenini kaybetmiş bir yığın haline gelen ayaktakımının devlete ve zenginlere karşı içsel bir isyanı ortaya çıkarmasının önemli sosyoekonomik ve politik riskleri beraberinde getirebileceği düşüncesiyle, Hegel'in sistemine içkin olası bir çözüm önerisi getirilmeye çalışılmıştır. Ayrıca, yoksulluk pek çok ülkenin ortak sorunu olsa da söz konusu ülkeler arasında ekonomik yapı, yönetim biçimi, gelir seviyesi ve demografi anlamında önemli farklııklar bulunması nedeniyle, çözüm önerisinin unsurlarının bir veya birden fazlasının bazı ülkeler için uygulanabilir olmayabileceği göz önünde bulundurulmalıdır.

\section{ORCID ID}

SEDA AKAY ATASOY

\section{Declaration of Conflicting Interests}

The author declared that there were no conflicts of interest with respect to the authorship or the publication of this article.
iD https://orcid.org/0000-0001-8736-7777

\author{
Çıkar Çatışması Beyanı \\ Yazar bu makalenin yazarlık veya \\ yayımlanmasına ilişkin olarak hiçbir çıkar \\ çatışması olmadığını beyan etmiştir.
}

\section{KAYNAKÇA}

Anderson, J. (2001). Hegel's Implicit View on How to Solve the Problem of Poverty: The Responsible Consumer and the Return of the Ethical to Civil Society. In R. Williams (Eds.), Beyond Liberalism and Communitarianism: Essays on Hegel's "Philosophy of Right" (pp.185-205). Albany, NY.

Aristoteles. (1998). Politics. (C.D.C. Reeve, Trans.). Hackett Publishing Company. Indianapolis/Cambridge. (Original Work Published in 384-322 B.C).

Avineri, S. (1972). Hegel's Theory of the Modern State. Cambridge University Press.

Bellamy, R. (1987). Hegel and Liberalism. History of European Ideas, 8(6), 693-708.

Bravo, I. B. (2006). Hegel ve Liberalizm. FLSF Felsefe ve Sosyal Bilimler Dergisi, 2. 19-30.

Brooks, T. (2015). Hegel and the Problem of Poverty. Kilikya Felsefe Dergisi, (1), 1-9. 
Ferro, B. (2020). Poverty and Recognition in Hegel's Philosophy of Right. G. Schweiger (ed.), Poverty, Inequality and the Critical Theory of Recognition, Philosophy and Poverty 3 (pp. 59-80).

Fraser, I. (1996). Speculations on Poverty in Hegel's Philosophy of Right, The European Legacy: Toward New Paradigms, 1(7), 2055-2068.

Fraser, N. \& Honneth, A. (2003). Redistribution or Recognition: A Political-Philosophical Exchange. London: Verso.

Geremek, B. (1994). Poverty: A History, (A. Kolakowska, Trans.). New Jersey: Blackwell Publishers. (Original Work Published in 1994).

Hegel, G. W. F. (1991). Hukuk Felsefesinin Prensipleri. (C. Karakaya, Çev.). Sosyal Yayınları. İstanbul. (Orijinal Basım Yılı 1820).

Hegel, G. W. F. (2001). Philosophy of Right. (S.W Dyde, Trans.). Batoche Books, Kitchener. (Original Work Published in 1820).

Hegel, G. W. F. (2018). The Phenomenology of Spirit. (T. Pinkard, Trans.). Cambridge University Press. United Kingdom. (Original Work Published in 1807).

Honneth, A. (2010). The Pathologies of Individual Freedom: Hegel's Social Theory. (L. Löb, Trans.). Princeton University Press. Princeton and Oxford. (Original Work Published in 2001).

Jackson, J. (2014). The Resolution of Poverty in Hegel's “Actual” State. Polity, 46(3), 331-353.

Kant, I. (1991). The Metaphysics of Morals. (M. Gregor, Trans.). Cambridge University Press. (Original Work Published in 1797).

Klikauer, T. (2013). Hegel on Profits, Poverty, and Politics. Radical Philosophy Review, 16(3), 789-799.

Locke, J. (1997). An Essay on the Poor Law. In M. Goldie (Ed.), Locke: Political Essays (Cambridge Texts in the History of Political Thought, pp. 182-198). Cambridge: Cambridge University Press. (Original Work Published in 1697).

Marx, K. (2004). Kapital 1. Cilt. (A. Bilgi, Çev.). Sol Yayınları. 7. Baskı. Ankara. (Orijinal Basım Yılı 1867).

Marx, K. (2005). 1844 El Yazmaları. (M. Belge, Çev.). Birikim Yayınları. 3. Baskı. İstanbul. (Orijinal Basım Yılı 1932).

Marx, K. \& Engels, F. (2005). Komünist Manifesto ve Komünizmin ilkeleri. (M. Erdost, Çev.). Sol Yayınları. 6. Baskı. Ankara. (Orijinal Basım Yılı 1847-48).

Melamed, Y. Y. (2001). Leaving the Wound Visible: Hegel and Marx on the Rabble and the Problem of Poverty in Modern Society. Iyyun: The Jerusalem Philosophical Quarterly, 50, 23-39.

Pimenta, T. L. (2020). The Abyss of Right: Hegel's Philosophy of Right and the Question of Poverty. Oeconomia, 10(4), 729-757.

Plant, R. (1977a). Hegel and Political Economy I. New Left Review, 103, 79-92.

Plant, R. (1977b). Hegel and Political Economy II. New Left Review, 104, 103-113. 
Plant, R. (1982). Dialectics, Politics and Economics: Aspects of Hegel's Political Thought. Revue Internationale de Philosophie, 36(139/140), (1/2), 49-68.

Platon. (2002). Devlet. (S. Eyüboğlu \& M. A. Cimcoz, Çev.). Türkiye İş Bankası Kültür Yayınları. İstanbul. (Orijinal Basım Yılı M.Ö. 375).

Ruda, F. (2011). Hegel's Rabble: An Investigation into Hegel's 'Philosophy of Right'. London: Continuum.

Ruda, F. (2017). That Which Makes Itself: Hegel, Rabble and Consequences. D. James (ed.). In Hegel's Elements of the Philosophy of Right: A Critical Guide. Cambridge, Cambridge University Press, pp.160-177.

Savran, G. A. (2013). Sivil toplum ve Ötesi: Rousseau, Hegel, Marx. Dipnot Yayınları. 1. Baskı. Ankara.

Schweiger, G. (2015). Recognition and Poverty. Eidos. 22. 143-168.

Smith, A. (2008). Milletlerin Zenginliği, (H. Derin, Çev.). Türkiye İş Bankası Kültür Yayınları. İstanbul. (Orijinal Basım Yılı 1776).

Smith, A. (2018). Ahlaki Duygular Kuramı. (D. Kızılay, Çev.). Pinhan Yayıncılık. İstanbul. (Orijinal Basım Yılı 1759).

Teichgraeber, R. (1977). Hegel on Property and Poverty. Journal of the History of Ideas, 38(1), 47-64.

Türkyılmaz, Ç. (2008). Spinoza ve Hegel'de Bilinç. Monokl, Hegel Özel Sayısı, IV-V, Yapı Kredi Yayınları, 271-277.

Türkyılmaz, Ç. (2015). Filozoflarla Düşünmek, Bibliotech Yayınları, Ankara.

Whitt, M. S. (2013). The Problem of Poverty and the Limits of Freedom in Hegel's Theory of the Ethical state. Political Theory, 41(2), 257-284.

Žižek, S. (2015). Hiçten Az: Hegel ve Diyalektik Materyalizmin Gölgesi. (Çeviren: E. Ünal, Çev.). Encore Yayınları, İstanbul.

\section{Sonnotlar}

\footnotetext{
' Bu çalışma yazarın Hacettepe Üniversitesi Felsefe Bölümü'nde tamamladığı "Hegel'de Yoksulluk Sorunu” adlı yüksek lisans tezinden türetilmiştir.

ii Žižek, bu talebin haksız bir talep olmadığını belirterek "ayaktakımı özgür, özerk hayatın evrensel alanından dışlandığından, talepleri başlı başına evrenseldir” ifadelerinde de dile getirdiği üzere ayaktakımının öfkesini haklı bulmaktadır (Žižek 2015: 435).

iii Melamed Marx'ın proletarya anlayışında Hegel'in ayaktakımına ilişkin yaptığı tespitlerin katkısı olduğunu ifade etmekte, ayaktakımının içinde bulunduğu utanç verici duruma yönelik yıkıcı aktivitesi ile proletaryanın kendisini proletarya yapan şeyin yok edilmesine ilişkin yıkıcı aktivitesini aynı görmektedir (Melamed 2001: 35). Klikauer ise ayaktakımı ve proletarya arasındaki temel ayrımın çalışma alışkanlığında olduğunu belirtmekte ve "ayaktakımını lümpen proletarya olarak gören Marx'ın aksine Ruda'nın ayaktakımı ve proletarya arasındaki keskin ayrımın farkında olmasına" rağmen ayaktakımından proletaryaya bir geçiş öngörmesinden dolayı Ruda’yı eleştirmektedir.
} 
Ona göre ayaktakımı çalışma alışkanlığını kaybederken proletarya çalışma edimine yabancılaşmış olsa da devam etmektedir (Klikauer 2013: 794).

iv Teichgraeber Hegel'in her bireyin gücünün ve potansiyelinin farkına varmasına ilişkin temel yükümlülüğü ortadan kaldırdığını düşündüğü komünizm düşüncesinin Hegel'in felsefi sistemi açısından kabul edilemez olduğunu belirterek Ruda'nın Hegel’den oldukça uzaklaştığını düşünmektedir. (Teichgraeber 1977: 58).

$\checkmark$ Plant'in yoksulluğun çözümüne ilişkin refah devleti temelli çözüm önerisi Teichgraeber tarafından eleştirilmektedir. Teichgraeber'a göre "refah devleti, bireylerin kendi kurtuluşları için geçimleri açısından devlete doğrudan bağımlı olduğu bir düzene" işaret etmekte, bu yüzden de "ekonomik bireyselliğin bir çözümü ya da çaresi olmaktan çok, bir koltuk değneği olmanın ötesine geçememektedir."(Teichgraeber 1977: 61).

vi Korporasyonların yaratabileceği böylesi bir soruna Teichgraeber da dikkat çekmekte ve tehlikeyi “... korporasyonlar arasında siyasi kendi çıkarını düşünen birimler olarak keskin bir rekabet oluşma olasılığı vardır. Korporasyonlar, sivil toplumun farklı kesimlerinin çıkarlarını savunurken onları sınırlandırması ve kontrol altına alması gereken bir yapı olan devletin kendisi ile siyasi rekabet içine girerler" ifadesi ile açıklamaktadır (Teichgraeber 1977: 61).

vii Jackson'ın bireylerin mağdur olmaması için korporasyonlarda devlet kontrolünü öngörmesi Plant'in devlet müdahalesini öngören refah devleti anlayışından farklılaşmaktadır. Çünkü Plant "devlet müdahalesini" sivil toplumdaki çalışma ilkesinin sürdürülebilirliği için verilmesi gereken bir ödün olarak görürken, Jackson "devlet kontrolünün" sivil toplumun içsel doğasını ve bağımsızlığını bozmayacağını savunmaktadır (Jackson 2014, 348).

viii Honneth, değer odaklı bir tanınma ilişkisi içermelerinden hareketle korporasyonların sivil toplum aşamasından ziyade devlet aşamasında yer alması gerektiğini öne sürmektedir. Diğer taraftan, bu çalışmada öne sürülen çözüm önerisinde sivil toplumun yapısı ve konumu Hegel'in düşünce sisteminde kalma amacı çerçevesinde mevcut haliyle korunmuştur.

ix Bu çalışmada tasarlanana benzer bir evrensel temel gelir uygulaması Jackson tarafından da önerilmekte, fakat söz konusu modelde yoksullukla mücadele korporasyonlar ve kamu otoritesi ile değil, devlet eliyle aşamalı bir biçimde yapılmakta, ayrıca evrensel temel gelir desteği herhangi bir şarta veya süreye bağlı olmaksızın uygulanmaktadır (Jackson 2014: 353). Yine de devletin Hegelci özgürlüğü gerçekleştirmesi için değişmeyen bir varlıktan ziyade sürekli ilerleme kaydeden bir güç olması gerektiğini vurgulayan Jackson'ın modeli burada önerilen model ile benzerlikler göstermektedir.

× Her ne kadar Hegel sivil topluma geçişte ahlaki ve entelektüel bir eğitime önem veriyor olsa bu çalışmada ortaya konulan çözüm önerisi eğitimin kapsamını korporasyonları da içerecek biçimde genişletmek yoluyla eğitimin sistem içindeki önemini artırmaktadır. 